\title{
GOVERNO DAS CONSCIÊNCIAS E CONTROLE MORAL: CONFESSIONALIZACÃO E A ATUACÃO DO CLERO NAS ILHAS FILIPINAS (1581-1617)
}

CARLOS GUILHERME ROCHA*

CENTRO FEDERAL DE EDUCACÃO TECNÓLOGICA

DE MINAS GERAIS

VARGINHA - MINAS GERAIS - BRASIL
RESUMO

RESUMEN
Analisa-se as concepções teológicas e jurídicas e a ação do corpo eclesiástico nas ilhas Filipinas, no contexto posterior ao Concílio de Trento, descrevendo as formas e as especificidades dos processos de reforma eclesiástica e confessionalização no arquipélago oriental. O período estudado é o governo episcopal de Domingo de Salazar e as duas primeiras décadas após a elevação da diocese à condição de arcebispado, estas marcadas por vacâncias no governo eclesiástico. São destacadas a atuação de instituições e os discursos caros à reforma católica, como o governo das consciências, o controle da Inquisição sobre os confessores, o clamor por visitações e a busca pela moralidade de fiéis e do clero. Nesse sentido, conclui-se que a ideia de frailocracia, que caracteriza as Filipinas como uma situação de desobediência generalizada do clero, na qual os freis gozariam de grandes liberdades políticas e sociais, não é um conceito apropriado.

Palavras-chave: Filipinas; Reforma Católica; Confessionalização.

Se analizan las concepciones teológicas y jurídicas y la acción del cuerpo eclesiástico en las islas Filipinas, en el contexto posterior al Concilio de Trento, describiendo las formas y especificidades de los procesos de reforma eclesiástica y confesionalización en el archipiélago oriental. El período estudiado es el gobierno episcopal de Domingo de Salazar y las dos primeras décadas después de la elevación de la diócesis a la condición de arzobispado, estas estuvieron marcadas por las vacantes en el gobierno eclesiástico. Se destaca la actuación de instituciones y discursos estimados por la reforma católica, como gobierno de conciencias, el control de la Inquisición sobre los confesores, el clamor por las visitas y la búsqueda de la moralidad de los fieles y del clero. En este sentido, se concluye que la idea de frailocracia, que caracteriza las Filipinas como una situación de desobediencia general del clero, en la que los frailes gozarían de grandes libertades políticas y sociales, no es un concepto adecuado.

Keywords: Filipinas; Reforma Católica; Confesionalización.

\footnotetext{
${ }^{*}$ Doutor em História (UFF) e Professor do Centro Federal de Educação Tecnológica de Minas Gerais (CEFET-MG). Este artigo apresenta os resultados da pesquisa de doutorado feita na Universidade Federal Fluminense, intitulada "Expansão da fé e justiça: o corpo eclesiástico e o governo das Ilhas Filipinas (1565-1610)". Pesquisa que contou com a concessão de bolsa do Conselho Nacional de Desenvolvimento Científico e Tecnológico (CNPq). E-mail: carlosgrocha@ cefetmg.br.
} 


\section{INTRODUCÃO}

Em oito de junho de 1598, o doutor Antonio de Morga escreveu ao Conselho das Índias longa relação sobre o estado das ilhas Filipinas. Os dois primeiros capítulos foram dedicados a denunciar excessos cometidos por clérigos e religiosos: davam péssimo exemplo aos fiéis com seus vícios, comportamentos indecentes, jogatinas, banquetes e festividades. Além disso, exploravam da mão de obra dos indígenas, tratando-os "como a perros o esclavos". No governo religioso eram igualmente abusivos, cobrando taxas excessivas para ministrar batismos, casamentos e funerais. ${ }^{1}$

Morga destacou três classes de problemas em relação ao clero local: desvios morais e sexuais; envolvimento em ações econômicas e ambição de enriquecimento; e usurpação da jurisdição temporal. Além de interferir em questões fora da alçada religiosa, os freis se valiam de dizer que eram membros do corpo eclesiástico para permanecerem impunes, mesmo cometendo tantos delitos.

Esse retrato do poder gozado pelos freis cruzou os séculos. A historiografia sobre as Filipinas consolidou a imagem da história colonial do arquipélago como uma experiência sui generis, na qual os freis e autoridades eclesiásticas gozariam de amplas liberdades e autonomias. Algo único, que não teria ocorrido nas demais ações coloniais ibéricas. As ordens religiosas, principalmente, conseguiriam influir e orientar a vida política e social das ilhas. Marco desta interpretação é o escritor Marcelo Hilario del Pilar, que no fim do século XIX publicou o panfleto La Frailocracia Filipina ${ }^{2}$, no qual defendeu que a experiência colonial filipina foi marcada pela enorme influência das ordens religiosas na história social e política.

Del Pilar era um dos membros do chamado "Movimento de Propaganda", que defendia a independência das Filipinas (ainda sob controle espanhol) e a plena laicização do Estado. ${ }^{3}$ A ideia de frailocracia cunhada pelo polemista filipino se tornou hegemônica para a compreensão

\footnotetext{
${ }^{1}$ Antonio de Morga é uma das figuras mais destacadas do primeiro século de colonização espanhola no arquipélago filipino. Formado em direito canônico pela Universidade de Salamanca, traçou carreira de sucesso na administração colonial, iniciando pelas Filipinas, em 1594, no cargo de teniente de governador. Nos dez anos em que serviu no arquipélago, ocupando variados cargos, redigiu Sucesos de las Islas Filipinas, que conta a história das Filipinas a partir do ponto de vista europeu, entre os anos de 1493 e 1603, quando Morga passou à No va Espanha. MORGA, Antonio de. Sucesos de las Islas Filipinas. Enriquecida con los escritos inéditos del mismo autor. Madri: Librería General de Victoriano Suárez, 1909, p. 247-263.

${ }^{2}$ DEL PILAR, Marcelo, La frailocracia filipina. Barcelona: Imprenta Iberica de Francisco Fossas, 1889.

${ }^{3}$ RIOS VICENTE, Enrique, "Marcelo H. del Pilar, el mejor comunicador filipino de finales del siglo XIX", Revista de la SEECI, n. 5, 2000; ORTIZ ARMENGOL, Pedro, Letras en Filipinas. Madri: Dirección General de Relaciones Culturales y Científicas, 1999.
} 
do passado colonial espanhol nas ilhas, marcando ensaios, manuais e pesquisas no último século. ${ }^{4}$

Em recente artigo, Manuela García-Garrido defendeu que, na passagem entre os séculos XVI e XVII, o clero regular das Filipinas foi marcado por sua autonomia e independência, o que impediu tanto a afirmação do poder colonial absoluto de Castela sobre as ilhas quanto da soberania e centralismo confessional da Igreja católica reformada no campo religioso. ${ }^{5}$ A autora lista uma série de situações de conflito envolvendo as ordens religiosas, poderes episcopais e autoridades seculares. Para García-Garrido, a insubordinação, tanto à hierarquia eclesiástica quanto aos representantes do poder régio, era a principal marca do clero filipino. Em suma, a reforma religiosa instaurada pelo Concílio de Trento não se aplicou nas ilhas, pois havia uma “desobediencia general del clero".

Neste artigo analiso o mesmo contexto, porém, acredito que a ideia de frailocracia não se sustenta. De forma geral, as análises que defendem esta tese padecem de dois problemas. O primeiro é conceitual, tomando como pressuposto a existência de um colonialismo absolutista, que garantiria a Castela plena autoridade sobre seus territórios e clero neles atuante. Abordando a matéria do ponto de vista jurisdicionalista do Antigo Regime ibérico, a compreensão do que se passou nas Filipinas é distinta. ${ }^{6}$ A segunda questão é de ordem metodológica. As críticas e desobediências dos freis saltam aos olhos, pois se pautam apenas na documentação produzida pelos opositores dos religiosos. A escrita e as versões dadas pelos próprios freis são praticamente ignoradas. Minha abordagem tratará também dessa documentação, não no sentido de equilibrar um suposto julgamento, mas de compreender as querelas eclesiásticas e jurídicas a partir de seus termos.

Retomemos o informe de Antonio de Morga. Este escrito é o documento que temos de mais próximo a um relato da frailocracia filipina. A leitura isolada dos dois capítulos iniciais

\footnotetext{
${ }^{4}$ CUNNINGHAM, Charles Henry, "The ecclesiastical influence in the Philippines", The American journal of theology, v. XXII, n. 2, 1918; CONSTANTINO, Renato, A History of the Philippines: from the Spanish Colonization to the Second World War. Nova Iorque: Monthly Review Press, 1975; DE LOS ARCOS, María Fernanda, Estado y clero en las Filipinas del siglo XVIII. Iztapalapa: Universidad Autónoma Metropolitana, 1988; GARCÍA-ABÁSOLO, António, "La primera exploración del Pacífico y el asentamiento español en Filipinas", In: Elizalde, M. (org.). Las relaciones entre España y Filipinas. Siglos XVI-XX. Madri: CSIC, 2002.

${ }^{5}$ GARCÍA-GARRIDO, Manuela, Desobediencia y conflictos en el clero de las islas Filipinas (1595-1615). Nuevo Mundo, Mundos Nuevos [em linha], 2015.

${ }^{6}$ HESPANHA, António M. Para uma teoria da história institucional do Antigo Regime. In: HESPANHA, A. (Org,). Poder e instituições na Europa do Antigo Regime: coletânea de textos. Lisboa: Gulbenkian, 1984; GARRIGA, Carlos. Orden jurídico y poder político en el Antiguo Régimen. Istor, n. 16, 2004.
} 
conflui com o quadro de frailocracia descrito por Marcelo del Pilar, Manuela García Garrido, dentre outros.

Porém, a relação do jurista possui outros capítulos. O mais extenso é dedicado aos problemas do governo secular, no qual o governador Francisco de Tello é muito criticado, com vários excessos seus elencados. Ao falar sobre a administração da justiça, Morga não poupou críticas aos alcaides-mores. Estes cometeriam uma série de agravos contra os nativos, com ações tão ou mais graves que os religiosos. A mesma sorte de denúncias era feita contra os encomenderos.

Colocada nessa perspectiva, o informe de Antonio de Morga apresenta mais uma terra completamente sem ordem e polícia do que uma frailocracia, propriamente. Se nesse meio os religiosos tivessem amplo domínio político e liberdade de ação, certamente governadores, juízes de índios e encomenderos não teriam as mesmas possibilidades. Não que as denúncias feitas fossem falsas, porém o discurso de calamidade visava chamar a atenção das autoridades castelhanas não só para o estado do arquipélago, mas também para sua própria atuação em busca de méritos e benefícios. A data da escrita é bastante significativa nesse sentido. Oito de junho de 1598 é o dia da refundação da Audiencia de Manila, no qual Morga passou a atuar como ouvidor. Ao descrever aquele estado, Morga justificava a necessidade do tribunal, assim como de mostrar os grandes empecilhos que passariam, o que demandaria mais investimentos, autoridade e possíveis prêmios.

Nos mesmos dias em que Morga escrevia a dita relação, o cabildo eclesiástico produziu um informe sobre o estado religioso do arquipélago. ${ }^{7}$ Os capitulares da catedral elogiaram jesuítas, franciscanos descalços e, especialmente, dominicanos por seus trabalhos, bom procedimento e bom exemplo. Era recomendado que o monarca os favorecesse. O cruzamento de fontes serve para possibilitar outros olhares e perspectivas sobre o contexto estudado.

Em outro trecho de seu informe, Morga afirmou que os eclesiásticos queriam intervir em todos os assuntos, "por via de consciencia y teologia". Tal informação é essencial para compreender os termos dos conflitos que ocorriam nas Filipinas. Os religiosos e padres agiam

\footnotetext{
${ }^{7}$ Archivo General de Indias (AGI), Carta do cabildo eclesiástico, Audiencia de Filipinas (Filipinas), 77, 8. Todos os documentos do Archivo General de Indias foram acessados digitalmente através do Portal de Archivos Españoles. Em < http://pares.mcu.es >.
} 
se valendo de autoridade religiosa, atuando no campo espiritual. Esse tipo de ação faz sentido dentro da concepção societária tomista, vigente no mundo católico do Antigo Regime e defendida pelos teólogos da chamada "Segunda Escolástica", que compreendia o mundo ordenado pela Lei Natural, implantada nos seres humanos e na ordem da criação, permitindo que as pessoas conhecessem as vontades de Deus. Esta compreensão colocava o clero em uma posição de preeminência na legitimação das ordens sociais e políticas. O principal referente do movimento intelectual citado, o dominicano Francisco de Vitória explica que:

El deber, la misión del Teólogo son tan extensos que no hay argumento alguno, no hay disputa, no hay lugar ajeno a la profesión e institución teológica. [...] Es la Teología la primera de las disciplinas y el primero de los estudios del mundo; por lo cual no es de maravillar que pocos se hallen competentes en tan dificil doctrina. $^{8}$

Ou seja, para descobrir se uma lei era justa e inspirada na Lei Natural, deveria se recorrer não a juristas, mas a teólogos. Vigorava o entendimento de que as potestades civil e espiritual deveriam confluir, buscando meios comuns para atingir suas finalidades distintas. Esse vínculo entre a política e religião, ou mais precisamente, entre a fidelidade ao soberano e a profissão religiosa, é uma das principais marcas da Monarquía Hispânica e da "Época Confessional". Como a finalidade do poder religioso seria superior (buscar a Salvação das almas) ela possuiria preeminência em relação aos interesses políticos. "Por tanto, lo temporal es por lo espiritual y depende de ello". ${ }^{10}$

Logo, as principais ações dos freis e padres atuantes nas Filipinas não se faziam por intromissões, desobediências ou usurpação de jurisdição alheia - como Morga assinalou. O clero se voltava para o controle do foro interno, da consciência. Através da moral, produziam

\footnotetext{
${ }^{8}$ VITÓRIA, Francisco. Relección de la potestad civil. In: Relecciones teologicas del p. fray Francisco de Vitoria. Madri: Librería Religiosa Hernández, 1917(a), T. II, p. 1.

${ }^{9}$ PROSPERI, Adriano. Tribunais da Consciência. Inquisidores, confessores, missionários. São Paulo: Edusp, 2013; PRODI, Paolo. Uma história da justiça: do pluralismo dos foros ao dualismo moderno entre consciência e direito. São Paulo: Martins Fontes, 2005; RODRIGUES, Rui Luis. Os processos de confessionalização e sua importância para a compreensão da história do Ocidente na primeira modernidade (15301650). Tempo, v. 23, n. 1, 2017.

${ }^{10}$ VITÓRIA, Francisco de. Relección de la postestad de la Iglesia. In: Relecciones teologicas del p. fray Francisco de Vitoria. Madri: Librería Religiosa Hernández, 1917(b), T. II, p. 265.
} 
pareceres sobre ordenanças, predicavam à população sobre sua maneira de agir e, principalmente, regulavam o sacramento da confissão e a concessão de absolvições.

\section{O GOVERNO EPISCOPAL DE DOMINGO DE SALAZAR (1581-1594)}

Os primeiros religiosos cristãos a atuarem no arquipélago filipino foram os agostinianos. Lá fundaram a província do Santíssimo Nome de Jesus. No fim da década de 1570, os franciscanos descalços também se dirigiram às ilhas. A primeira fase da colonização, entre 1565 e 1581, é marcada por atritos entre religiosos e colonos, com aqueles defendendo - em pareceres, em notícias, nos púlpitos e nos confessionários - as liberdades dos povos nativos e a execução de uma política pacífica e amistosa em relação aos mesmos. ${ }^{11}$

Em 1581, a fundação do bispado de Manila, chefiado pelo frei dominicano Domingo de Salazar, marcou uma nova fase na política colonial e eclesiástica das Filipinas. Salazar estudou em Salamanca e era considerado de grande doutrina e letras, além de possuir muita experiência na conversão do gentio no México. ${ }^{12} \mathrm{Na}$ Espanha foi discípulo de Francisco de Vitória e outros destacados teólogos da Segunda Escolástica ibérica, como Melchor Cano e Domingo de Soto. Outra inspiração sua foi o também dominicano Bartolomé de las Casas. ${ }^{13}$

$\mathrm{Na}$ Reforma Católica, a figura do bispo passou a ser ainda mais importante. Era ele o responsável pela evangelização e pelo cuidado dos fiéis. Assumia assim a figura de "pastor", referência para a uniformização institucional e confessional pretendida pelo concílio ecumênico de Trento. ${ }^{14}$ É importante salientar que o Concílio de Trento não foi o encerramento de uma etapa, um esquema que se impôs por completo e absolutamente, mas deu início a uma época de criação. Portanto, é preciso evitar esquemas explicativos prontos e analisar as experiências religiosas e institucionais estimuladas pela assembleia, analisando como, na prática e em

\footnotetext{
${ }^{11}$ GARCÍA-ABÁSOLO, Antonio. Relaciones entre los grandes virreyes de México y los agustinos ante la presencia española en Filipinas (siglo XVI). In: Actas del congresso internacional: Agustinos en América y Filipinas, Valladolid: Banco Atlántico, 1990, v. 2; HIDALGO NÚCHERA, Patricio. Encomienda, tributo y trabajo en Filipinas (1570-1608). Madri: Universidad Autónoma de Madrid, 1995; ROCHA, Carlos. Para a conversão das almas: conquista espiritual, governo civil e defesa dos nativos nas Filipinas. A época missionária, $1565-1581$. Diálogos, v. 20, n. 2, 2016.

${ }^{12}$ AGI, Consulta del consejo de Indias, Indiferente General, 739, 99.

${ }^{13}$ AGI, Cartas de Domingo de Salazar al rey, Patronato Real, 25, r. 8.

${ }^{14}$ PROSPERI, Adriano. Il Concilio di Trento: una introduzione storica. Turim: Giulio Einaudi, 2001, p. 81-83.
} 
diversas regiões, os fiéis e as instituições eclesiásticas se adaptaram e estabeleceram um novo modelo de Igreja. ${ }^{15}$

Em seu primeiro mês nas Filipinas, o bispo Domingo de Salazar manteve a linha de atuação de agostinianos e franciscanos na defesa dos nativos, defendendo a abolição da escravidão dos indígenas do arquipélago. Diante da oposição de regidores, encomenderos e do governador Gonzalo Ronquillo, o bispo Salazar sinalizou que os religiosos recriminassem aqueles que possuíam escravos nativos, durante as pregações e confissões, e que nestas não concedessem absolvição enquanto não libertassem os indígenas mantidos em cativeiro. ${ }^{16}$

Se a relação do bispo com as autoridades seculares foi difícil, com o corpo eclesiástico não foi diferente. O bispo promoveu a secularização de várias missões (ou seja, tirando-as do controle das ordens religiosas), bem como assumiu o controle sobre processos eclesiásticos movidos contra nativos. Os freis de Santo Agostinho não aceitaram passivamente tais medidas, resistindo a cumprir seus mandatos. Para justificar suas decisões, o bispo afirmava que agia "como juez delegado de su santidade conforme al santo consilio". De acordo com os informes de Salazar, os agostinianos tentavam governar mais povoados do que conseguiam, abandonando os indígenas por longos períodos, permitindo que recaíssem em suas "idolatrias". Diante disso, em janeiro de 1582, o bispo Domingo de Salazar determinou que os religiosos da ordem de Santo Agostinho não mais predicassem ou confessassem naquela diocese sem licença e aprovação sua, "conforme a lo que el dho dispone y esta determinado en el santo consilio trindentino". ${ }^{17}$

Em resposta, o prior agostiniano, frei Francisco Manrique, declarou que sua ordem não respondia à autoridade episcopal e que seus freis continuariam a administrar livremente os sacramentos e a justiça eclesiástica nos povoados sob seus cuidados. Tal atitude pode ser tomada como desobediência, no entanto, a argumentação agostiniana sustentava que possuíam “ordenes [y] poder de su sanctidad" para administrar plenamente suas doctrinas. De acordo

\footnotetext{
${ }^{15}$ DE BOER, Wietse. The conquest of the soul. Confession, discipline and public order in counter-reformation Milan. Boston: Brill, 2001, $\mathrm{p}$. 172; PÉREZ PUENTE, Leticia. El obispo. Político de institución divina. In: MARTÍNEZ, Maria (Org.). La Iglesia en Nueva España. Problemas y perspectivas de investigación. México: UNAM, 2010, p. 154.

${ }^{16}$ AGI, Registro de ofício y partes de disposiciones reales, Filipinas, 339, L. 1, imgs. 141-142; AGI, Parecer de religiosos sobre cédula de la esclavitud, Filipinas, 84, 21.

${ }^{17}$ AGI, Carta de Domingo de Salazar sobre conflicto con Diego de Mujica, Filipinas, 84, 24, img. 62.
} 
com Manrique, sua ordem gozava de diversos "prebilegios que tenian del papa". ${ }^{18}$ Diversas vezes os freis destacaram explicitamente beneplácitos recebidos de Paulo II, Adriano VI e outros pontífices. O discurso dos freis não era de oposição ou rebeldia, mas de justiça e obediência. ${ }^{19}$ A rejeição em cumprir uma ordem episcopal, era apresentada como meio de manter os desígnios papais e régios para a região das Filipinas, garantindo a efetivação da conversão dos neófitos e a busca pelo "bem comum".

Por mais que o bispo Salazar tentasse impor sua autoridade e passar doctrinas e paróquias ao controle de seus beneficiados, não poderia renunciar à atuação das ordens religiosas. Um informe episcopal de 1585 destacou que havia 102 missionários atuando no arquipélago, e que precisavam ao menos do triplo para cuidar devidamente da região. Dessa centena, 54 eram agostinianos e 38 franciscanos descalços. ${ }^{20}$ Nessa época, os freis das duas ordens abandonavam alguns de seus povoados, em represália à tentativa do bispo de infligir direta supervisão e correção de sua autoridade sobre os religiosos. Uma das determinações que provocou maior reação foi de que os religiosos passassem a atuar como missionários "de justicia y obligación y no de caridad". ${ }^{21}$ Isso daria direito ao bispo de visitar as casas das ordens, verificar seus registros e finanças. Ademais, evangelizadores e confessores só poderiam atuar após exame e licença episcopal.

Para os superiores das ordens, tal fórmula era um inconveniente e uma afronta aos estatutos de suas regras, por isso afirmaram que obedeceriam à cédula régia, mas não a cumpririam, para o bem da conversão dos nativos. O custódio franciscano, Juan de Plasencia, argumentou que o cuidado espiritual dos nativos e a administração de jurisdição eclesiástica lhes foram dados por privilégios de vários papas, "que nos conçeden in utroque foro toda su omnimoda autoridad". ${ }^{22}$

Orientado pela Audiencia de Manila, o bispo argumentou que os cânones do Concílio de Trento haviam revogado todos os privilégios papais citados por franciscanos e agostinianos. No

\footnotetext{
${ }^{18}$ AGI, Carta de agustinos en favor de Acuña y pidiendo religiosos, Filipinas, 84, 30, img. 2.

${ }^{19}$ MACKAY, Ruth. The limits of Royal Authority: resistance and obedience in seventeenth-century Castile. Nova Iorque: Cambridge University Press, 1999.

${ }^{20}$ Archivo Historico Nacional [Espanha] (AHN), Estado religioso en Filipinas, Diversos-colecciones, $26,10$.

${ }^{21}$ AGI, Carta de la Audiencia de Manila sobre religiosos e clérigos, Filipinas, 18 a, 5, 33, img. 1.

${ }^{22}$ AGI, Causa contra religiosos sobre doctrinas de índios, Filipinas, 84, 55, img. 56.
} 
entanto, diante dos prejuízos à evangelização, o bispo Salazar cedeu e suspendeu parcialmente aplicação dessa medida. As duas ordens religiosas não ficaram satisfeitas, exigindo que nada fosse alterado na administração religiosa do arquipélago.

O provincial agostiniano, frei Diego Muñoz, afirmou que Domingo de Salazar não estava interessado apenas em controlar a evangelização no arquipélago, mas também em beneficiar os dominicanos, sua ordem de origem. Os pregadores se estabeleceram nas Filipinas durante o governo de Salazar, e logo ocuparam lugar de destaque. Assim que a província dominicana do Santíssimo Rosário foi instituída, em 1587, imediatamente foi beneficiada com o governo dos sangleyes (termo usado pelos hispânicos para se referir aos chineses estabelecidos nas Filipinas). De acordo com o bispo Salazar, os pregadores se destacaram no domínio do idioma chinês, por isso a missão de evangelizar esse grupo foi a eles destinada. O mosteiro dominicano foi edificado ao lado do bairro chinês em Manila, o Parián. Os agostinianos, então responsáveis por esse grupo, protestaram. Frei Francisco de Ortega escreveu: "que por ser el obispo frayle dominico favoresçe a su orden y a ellos [agostinianos] los persigue". ${ }^{23}$ O governo espiritual sobre os sangleyes não era uma vantagem apenas local, mas visava favorecer os dominicanos na sonhada entrada no Celeste Império chinês. ${ }^{24}$

Durante as disputas citadas anteriormente, o vigário-geral dos dominicanos, Juan de San Vicente, apoiou as ações de Salazar. O crescimento e ocupação prestigiosa da ordem dominicana mostra como o bispo Salazar não foi um refém das demais ordens religiosas.

A postura hierárquica e centralizadora de Salazar, por mais que tenha sido contestada, teve seus efeitos. Dessa forma, não se observa uma frailocracia. As ordens sofreram uma sucessão de limitações, por vezes assumindo a derrota diante do poder episcopal. Conflitos resultantes de uma pretendida imposição do controle e poder episcopal não foram uma especificidade filipina, ocorrendo, por exemplo, na Nova Espanha e no Peru. ${ }^{25}$ Mais que isso,

\footnotetext{
${ }^{23}$ AGI, Carta del fiscal Ayala sobre situación general, Filipinas, 18 a, r. 7, 49, img. 8.

${ }^{24}$ CREWE, Ryan Dominic. Pacific Purgatory: Spanish dominicans, chinese sangleys, and the entanglement of mission and commerce in Manila, 1580-1620. Journal of Early Modern History, v. 19, n. 4, 2015; OLLÉ RODRÍGUEZ, Manel. Estrategias filipinas respecto a China: Alonso Sánchez y Domingo Salazar en la empresa e China (1581-1593). Tese (Doutorado), Universitat Pompeu Fabra, Barcelona, 1998; CERVERA, Antonio. Los dominicos y los chinos de Manila: Domingo de Salazar y Juan Cobo en Filipinas, 1581 -1592. In: FUENTES, Paulina et. Al [coords.]. Pensamiento en México: tradiciones multiculturales. São Luis Potosi: Ed. UASLP, 2020.

${ }^{25}$ LUNDBERG, Magnus. Church life between the Metropolitan and the local. Parishes, parishioners and parish priests in seventeenth-century Mexico. Madri: Iberoamericana, 2011; RUBIAL, A. Las ordenes mendicantes evangelizadoras en Nueva España y sus câmbios estructurales durante los siglos vierreinales. In: MARTÍNEZ, Maria (Org.). 2010
} 
o bispo teve importante atuação, como líder do corpo eclesiástico, no estabelecimento de modos de agir para mediar a relação entre os colonos europeus e os nativos.

No entanto, Salazar não obteve apenas sucessos. Sua tentativa em atuar como "inquisidor ordinário" - tal como bispos faziam antes da fundação dos tribunais do Santo Ofício na América - foi frustrada. Em 1583, o frei agostiniano Francisco Manrique foi nomeado como comissário da Inquisição mexicana, para atuar no arquipélago. Pelos três anos seguintes, o bispo Salazar contestou os títulos do frei ${ }^{26}$, e continuou a mover, da sua forma, causas inquisitoriais em Manila, inclusive com julgamentos e realização de autos-de-fé. ${ }^{27}$ Em 1586, os inquisidores mexicanos anularam a validade da atuação inquisitorial do bispo, confirmando a posição de frei Manrique. Salazar não contestou, mas continuou a criticar o controle agostiniano sobre a instituição inquisitorial na sua diocese. Tanto que ainda na década de 1580, o prelado diocesano recomendou que a comisaría filipina fosse dada ao frei Cristoval de Salvatierra, dominicano. ${ }^{28}$ A distinção entre atuação inquisitorial da ação pastoral dos bispos foi uma das importantes consequências do Concílio de Trento, especialmente no Novo Mundo.

Em relação às cédulas régias ordenando a secularização das doutrinas e o controle episcopal sobre as mesmas: também não houve aceitação passiva. Isso não necessariamente caracteriza em desobediência por parte dos freis atuantes no arquipélago. Não existia um quadro de absolutismo jurídico. O direito e o justo não eram emanados, como ato criativo, por uma autoridade soberana, o poder régio. Mas era sim uma busca pela justiça estabelecida em tempos eternos. Essa busca não visava estabelecer um código de regras positivas universais, mas garantir o bem comum. Como a natureza humana era considerada diversa, bem como as situações das sociedades humanas diversas no tempo e no espaço, as normas também deveriam ser distintas, sempre no intuito de colocar as pessoas no caminho do bem. Esses pressupostos comuns e gerais davam margem para práticas singulares e variadas. ${ }^{29}$

\footnotetext{
${ }^{26}$ Archivo General de la Nación [México] (AGN), Inquisición, v. 139, imgs. 7-10; AGN, Cartas del licenciado Davalos oidor del Santo Oficio para los señores inquisidores de México, Indiferente Virreinal, c. 5025, exp. 25; AGI, Carta de la Audiencia de Manila sobre situación y necesidades, Filipinas, 18 a, 3, 13; AGI, Carta de Vera sobre necesidades, indios, minas etc, Filipinas, 18 a, 3, 15.

${ }^{27}$ PALANCO AGUADO, Fernando. Los primeros años de Inquisición en Filipinas. Jueces eclesiásticos, el obispo Domingo de Salazar y los comisarios agustino fray Francisco Manrique y fray Diego Muñoz (1577-1594). Archivo Augustiniano, v. 102, n. 220, 2018, p. 89-95.

${ }^{28}$ AGN, Inquisición, 142; AGN, Inquisición, 86, img. 111.

${ }^{29}$ GARRIGA, Carlos. Sobre el gobierno de la justicia en Indias (siglos XVI-XVII). Revista de Historia del Derecho, n. 34, 2006, 72-84; PROATTI, Elaine. Consciência e lei: os embates subjetivos e teológicos nos pareceres do Padre Fray Miguel Agia. Dissertação de mestrado. São Paulo: Unifesp, 2015; RUIZ, Rafael. Os espaços da ambigüidade: os poderes locais e a justiça na América Espanhola do século XVII. Revista de História, n. 163, 2010.
} 
Não era ambição do governo régio castelhano que suas ordenações fossem seguidas mecanicamente. Desvios, adaptações e recusas eram previstos e admissíveis, desde que buscassem evitar um mal maior ou conseguir um bem superior. A objeção a determinações e ordens provenientes do poder régio castelhano - como as aqui destacadas - não era rara, mas fazia parte da prática e cultura administrativa hispânica. O discurso em torno de tais discordância, no entanto, não era o de oposição e confronto, mas, como vimos, sim de obediência e de justiça. A sustentação para o não cumprimento de uma ordem régia tinha por objetivo preservar a consciência do monarca, evitando que sua decisão fosse prejudicial ao "bem comum".

\section{SÍNODO DE MANILA E O GOVERNO DAS CONSCIÊNCIAS}

Em meio aos conflitos envolvendo a autoridade episcopal e os religiosos, o bispo Domingo de Salazar, a partir do ano de 1582, passou a convocar juntas eclesiásticas, que em seu conjunto ficou conhecido como primeiro Sínodo Diocesano de Manila. Stricto sensu não se tratava de um sínodo diocesano, pelos procedimentos e formalidades que deveriam ocorrer antes e durante o evento. Por conta disso, alguns autores argumentam que eram apenas juntas eclesiásticas. No entanto, José Luis Porras Camuñez, principal historiador do evento, afirma o caráter sinodal das reuniões, por terem sido chefiadas pelo bispo Domingo de Salazar e contado com a presença de diversos religiosos e clérigos de sua diocese ${ }^{30}$ Além disso, tanto o cabildo de Manila, quanto a Audiencia das Filipinas denominaram as juntas presididas por Domingo de Salazar de "sínodo". ${ }^{31}$

Como consequência de uma das juntas, em 1583, o bispo Domingo de Salazar escreveu ao Conselho das Índias um longo memorial, afirmando que a miséria da qual padeciam os nativos do arquipélago derivava única e exclusivamente da presença hispânica na região. Violência, mortes, fome e abusos faziam parte do cotidiano dos indígenas, que por tantas

${ }^{30}$ PORRAS CAMUÑEZ, José Luis. La posición de la Iglesia y su lucha por los derechos del indio filipino en el siglo XVI. Tese (Doutorado), Universidade de Sevilha, Sevilha, 1985.

31 AGI, Carta de la Audiencia de Manila sobre situación y necesidades, Filipinas, 18 a, r. 3, 13, img. 5; AGI, Carta del cabildo secular de Manila sobre asuntos generales, Filipinas, 34, 62; AGI, Carta de Vera pidiendo plaza de oidor de México, Filipinas, 18 a, r. 3, 17, img. 5-7. 
injustiças a eles cometidas "no acuden a la doctrina". ${ }^{32} \mathrm{O}$ bispo deixou claro que o problema não estava na Igreja nem na Monarquía, mas nos colonos que não obedeciam "las santas leyes y ordenanzas que para el buen govierno destas tierras [que] V. M. tiene hechas y mandadas guardar".

O termo que o bispo utiliza para definir tal situação merece destaque: escândalo. Esse termo tornou-se mais presente nos discursos religiosos pós-Trento. $\mathrm{O}$ escândalo era o erro que, pelo exemplo, estimulava outras pessoas a um comportamento ruim. Sendo pecados públicos, deveriam ser corrigidos publicamente. ${ }^{33}$ A concepção confessional para o governo religioso era combater não apenas o pecado, mas também as "situações de pecado". Cobrar tributos excessivos ou abusar dos nativos não eram pecados, mas se tais situações provocassem pecados, por exemplo, afastando os neófitos da prática do cristianismo e os incentivando a voltar a suas idolatrias, deveriam ser repreendidas pelo corpo religioso. Esse ponto é essencial para compreender o caráter "secular" (assim classificado por contemporâneos e por parte da historiografia) do Sínodo de Manila.

A primeira página da documentação sinodal salienta como motivos para a realização da assembleia as grandes dificuldades e os escrúpulos para escutar e ministrar confissões, por isso, naquela reunião definiram as questões que deveriam ser reparadas nas confissões, "para quietud y paz de las conciencias, así de los confesores como de los penitentes". ${ }^{34}$

Os clérigos e religiosos afirmaram que buscariam criar determinações que servissem às circunstâncias daquela terra, que era "nova" e afastada. O Sínodo é explícito ao dizer que não trataria simplesmente de aplicar normais gerais e alheias. Prevalece, assim, uma postura probabilista, que recomendaria as melhores medidas possíveis, que poderiam não ser perfeitas, mas seriam buscadas na verdade e na justiça estabelecida a ordenação natural.

Os eclesiásticos escreveram que seu objetivo era oferecer justiça às relações mantidas entre indígenas e hispânicos, impedindo que estes causassem agravos aos primeiros. No

\footnotetext{
${ }^{32}$ Memorial de las cosas que en estas yslas Philipinas de Poniente pasan y del estado de ellas y de lo que hay que remediar, hecho por fray Domingo de Salazar, Obispo de las dichas yslas, Para que lo vea Su Magestad y los Señores de su Real Consejo de Yndias. 1583. China en España (CHE). "Elaboración de un corpus digitalizado de documentos españoles sobre China de 1555 a $1900 "$. Disponível em: < http://www.upf.edu/asia/projectes/che/principal.htm >

${ }^{33}$ DE BOER, 2001, p. 63.

${ }^{34}$ PORRAS CAMUNEZ, 1985, p. 1560.
} 
entanto, as determinações do Sínodo de Manila se dirigiam diretamente aos predicadores e confessores estabelecidos no arquipélago. Ou seja, os erros e as injustiças cometidas nas Filipinas seriam corrigidos não por sanções civis ou criminais, mas através do controle e regulação das consciências. A assembleia clerical tratou exclusivamente de matéria religiosa, isto é, sobre as predicações e principalmente sobre o sacramento da confissão. Através destes dois instrumentos, de potestade religiosa, a Igreja poderia agir e moldar seus fiéis. Para fazer avançar a evangelização nas ilhas Filipinas, o Sínodo de Manila entendeu que deveria orientar as atitudes de autoridades seculares. Na concepção daqueles, não se tratava de uma intromissão de eclesiásticos no poder temporal, mas de meio para garantir o sucesso da finalidade mais importante: a Salvação das almas.

A primeira parte do Sínodo aborda dez categorias de seculares, no que suas ações, direitos e obrigações tangiam à evangelização do gentio filipino. São os seguintes: 1) o rei de Castela; 2) governadores do arquipélago; 3) oficiais reais; 4) alcaides maiores e justiças; 5) capitães e soldados; 6) encomenderos; 7) marinheiros, comissários e outros que tratam de assuntos referentes à Real Hacienda; 8) demais espanhóis que tratavam com os nativos; 9) principais indígenas; e 10) sangleyes que residiam ou comercializavam nas Filipinas.

A assembleia considerou que a única autorização que os monarcas e seus delegados haviam recebido era de financiar e promover a evangelização. Os delegados temporais dos reis cristãos serviriam apenas para amparar e assegurar a predicação, não para impor a fé e o domínio a povos alheios. Ou seja, os poderes existentes entre os próprios nativos eram legítimos e deveriam ser respeitados. Aqueles que se convertessem e passassem, voluntariamente, à submissão dos reis de Castela, aí sim seriam governados por autoridades de origem ibérica. Porém, os colonos hispânicos apoderavam-se das terras e retiravam os governos lá constituídos, agindo injustamente. O problema não era com os reis de Castela, pois estes enviavam ordens “tan cristianas y prudentes", mas sim no fato de elas não serem cumpridas por seus subalternos, que apenas desejavam realizar seus próprios interesses e vontades com a conquista das ilhas orientais. Dessa forma, era justo que Castela mantivesse seu domínio sobre as Filipinas, pois buscava converter os nativos. Era preciso que o rei corrigisse os malfeitos de seus delegados e oficiais. 
O bispo Domingo de Salazar e seus colegas, para justificar o domínio espanhol, não recorreram a teses de domínio universal, seja do papa ou dos monarcas cristãos, criticadas pela Segunda Escolástica, mas o fizeram a partir dos argumentos desta linha teológica. A referência implícita nos decretos do Sínodo é Francisco de Vitória. Segundo o teólogo espanhol, os nativos do Novo Mundo, não estavam obrigados a acreditar na fé cristã, ou seja, possuíam livre arbítrio para se manter na infidelidade, sem que isso atingisse seu domínio temporal. No entanto, o teólogo dominicano sugere que os índios seriam em parte "amentes", isto é, ignorantes e não completamente preparados para estabelecer um governo legítimo, baseado nos preceitos da lei natural, pois "no tienen leyes convenientes ni magistrados; ni siquiera son idóneos para gobernar la familia." 35 O discurso de Francisco de Vitória e dos decretos do sínodo caminham no mesmo sentido. Os nativos americanos e filipinos seriam como crianças órfãs, necessitadas de tutela e cuidado, assim seria justo que os espanhóis (mais sábios) os governassem para seu bem. Segundo Vitória, este fundamento se assenta no preceito da caridade cristã.

Ponto importante é que Vitória diz ter grande tendência a concordar com este título para o domínio, mas não o afirma como legítimo, como o faz com os outros por ele apresentados. Portanto, os participantes do Sínodo, baseados em sua experiência ultramarina, apropriam-se de maneira criativa do argumento do famoso frei dominicano, sem apresentar a ressalva feita por este.

Como a finalidade era "predicar el Evangelio", o Sínodo determina "que el confesor esté muy sobre aviso de los muchos daños que los soldados hacen a los naturales". ${ }^{36}$ Dentre eles limitar a liberdade comercial dos nativos, seu livre trânsito ou atentar contra seus bens materiais. O contato deveria sempre ser de forma pacífica, com amor. Tributos apenas poderiam ser cobrados de povos já pacificados e que tivessem voluntariamente estabelecido amizades com os espanhóis, "porque los indios eran tan libres en su tierra como los españoles en la suya, y esta libertad no se la ha quitado el Rey ni el Evangelio". ${ }^{37}$ Além disso, a junta eclesiástica orienta que o governador espanhol nas Filipinas consultasse seu confessor antes de instituir um valor para os tributos.

\footnotetext{
${ }^{35}$ VITÓRIA, 1917(b), p. 85.

${ }^{36}$ PORRAS CAMUÑEZ, 1985, p. 1581.

37 PORRAS CAMUNEZ, 1985, p. 1477.
} 
Com a confissão, a Igreja e o clero possuíam um meio privilegiado para alinhar as práticas e pensamentos dos fiéis. Por isso, mais que ouvir as confissões e conceder as absolvições, os clérigos estabelecidos nas Filipinas criaram estratégias e mecanismos para que as confissões permitissem a eles amplo conhecimento e influência sobre o que se passava nas ilhas. Caso os confessores não fizessem as admoestações assinaladas pelo Sínodo, pecariam mortalmente, assim como os próprios governadores e demais autoridades seculares. Era função do clero anunciar a todos o que era justo e o que era injusto, para que os poderes temporais corrigissem as faltas, punissem os malfeitores e restituíssem os danos cometidos contra os prejudicados.

Cabildo e Audiencia de Manila escreveram missivas criticando a junta eclesiástica e a atuação do bispo Domingo de Salazar. O governador Santiago de Vera afirmou que ao tratar daqueles temas, os religiosos e clérigos agiam "en perjuic ${ }^{\circ}$ de vra real jur.on". ${ }^{38}$ De acordo com o presidente da Audiencia, as ações tomadas pelos eclesiásticos deixaram muitos colonos aflitos.

Diversos exemplos mostram que, de fato, a partir do controle das consciências os religiosos influenciaram consideravelmente da população e as políticas coloniais nas Filipinas.

No fim da década de 1580, o Conselho das Índias impôs uma série de restrições protecionistas ao comércio dos chineses no arquipélago, como a instituição da pancada, medida que obrigava aos comerciantes da China a vender todo o carregamento de sua embarcação a um colono, a preços tabelados pelo governo hispânico. ${ }^{39}$ Mesmo confirmada por ordem régia, o bispo e os religiosos se opuseram, negando absolvição às pessoas designadas para comprar os produtos dos comerciantes chineses. Segundo eles, a medida era prejudicial aos vecinos de Manila e tirava a natural liberdade de comércio dos sangleyes. O capitão Luis de Bivanco, um dos indicados para fazer a compra da pancada, depois de ser alvo dos escrúpulos lançados pelos religiosos caiu enfermo e temendo morrer em pecado "hizo una escrptura en que mando se pagasen los dhos daños y para que se pasen de su hazi.da obligo todos sus bienes". ${ }^{40}$ Após isso foi absolvido.

${ }^{38}$ AGI, Carta de la Audiencia de Manila sobre situación y necesidades, Filipinas, 18a, r. 3, 13, img. 5.

${ }^{39}$ AGI, Expediente sobre comercio de Filipinas con China, Filipinas, 18a, r. 8, n. 53

${ }^{40}$ AGI, Carta de la Audiencia de Manila sobre situación y necesidades, Filipinas, 18 a, r. 3, 13, img. 11. 
O mesmo mecanismo serviu para que colonos cumprissem mandatos como a cédula que exigia a libertação de todos os nativos escravizados. Como o governo local não a fazia cumprir, o bispo e os religiosos decidiram que somente confessariam donos de escravos se estes se comprometessem a libertar seus cativos no prazo de até dois anos. Diante dessa pressão, o governador Diego Ronquillo se viu obrigado a executar a cédula. Além disso, os freis interferiram na instituição entre os próprios nativos, orientando que as lideranças locais libertassem seus escravos, ameaçando não os absolver caso não o fizessem. ${ }^{41}$

Em 1591, o governador Gómez Dasmariñas escreveu: “el imperio y auctoridad conq se hazen aqui los frailes superiores para arbitrar lo bueno y lo malo y q no aya otra ley justa sino la que ellos aprueban". ${ }^{42}$ As reclamações de Dasmariñas encontraram defensores no Conselho das Índias, preocupados com "la absoluta mano y poder que los rreligiosos tienen en estas yslas sin tocarles de derechos" ${ }^{43}$, deixando aos colonos aflitos e desconsolados, evitando se confessar. $^{44}$

Segundo o bispo de Manila, o rei poderia perdoar os conquistadores por seus abusos, mas que, no foro interno, não havia liberdade para concessão de indultos ou remissão de penas. No tribunal das consciências, escreveu Salazar, a confissão deveria ser rigorosa. ${ }^{45} \mathrm{O}$ rei espanhol além de não ser senhor do mundo, também não era o governante da moral. Este campo cabia aos juízes da consciência, os clérigos, como aqueles capazes de descobrir e revelar os ditames divinos.

Apesar dos conflitos, a atuação do bispo Salazar, com a realização das juntas eclesiásticas e com a produção de normativas sinodais, serviu não apenas para estabelecer mecanismos de controle, atuação e correção pelo clero filipino. As reuniões colegiadas, das quais os superiores das ordens e o poder episcopal participavam, serviram para a formação de unidade do clero uma pretensão formalizada no Concílio de Trento. Criava-se assim, uma conduta eclesiástica nas Filipinas, ao menos no que tangia à proteção dos indígenas e dos chineses.

\footnotetext{
${ }^{41}$ AGI, Copia de carta sobre estado de las Filipinas y posibilidades del comercio, Filipinas, 79, 1, img. 1; AGI, Descubrimientos, poblaciones de españoles: Filipinas, Patronato Real, 23, 9; Sobre as formas de escravidão existentes entre os nativos arquipélago ver: NADEAU, Kathleen. The history of the Philippines. Londres: Greenwood, 2008.

${ }^{42}$ AGI, Carta de la Audiencia de Manila sobre situación y necesidades, Filipinas, 18 a, r. 3, 13, img. 5.

${ }^{43}$ AGI, Información sobre negativa del obispo a dar doctrina, Filipinas, 6, 7, 77, img. 8.

${ }^{44}$ AGI, Registro de ofício y partes de disposiciones reales, Filipinas, 339, L. 1, img. 721.

45 AGI, Carta de Domingo de Salazar resumiendo seis cartas, Filipinas, 74, n. 35.
} 
Os discursos de governadores das Filipinas como Santiago de Vera, Diego Ronquillo e Gómez Dasmariñas podem ser tomados como prova que sustenta a tese da frailocracia filipina. Religiosos independentes, desobedientes a autoridades civis, ocupando espaços da jurisdição régia. Porém, é preciso compreender a concepção que tais autoridades tinham em relação ao espaço das instituições eclesiásticas. Em uma carta ao Conselho, Dasmariñas reclamou que Domingo de Salazar se dizia “obispo por el papa e no por V. Md.”. ${ }^{46}$ Aos ouvidos dos poderes seculares poderia ser um absurdo, pois deviam obediência ao monarca e não esperavam menos dos eclesiásticos. Mas as palavras de Salazar estavam plenamente de acordo com os preceitos eclesiásticos da época.

Do lado de Salazar e dos religiosos, as denúncias de abusos cometidos por governadores, encomenderos e oficiais pululavam. Por mais que conseguissem intervir, o quadro geral ainda estava longe do ideal. A evangelização ainda padecia de muitos percalços por conta de atos injustos cometidos pelos colonos. Um quadro distinto da frailocracia. Assim, o bispo Domingo de Salazar, mesmo em idade avançada, partiu a Castela, em junho de 1592, com intenção de intervir a favor dos nativos na questão da tributação. Antes de partir, a pressão exercida pelo bispo surtiu efeito, com a promulgação, pelo governador Dasmariñas, das “Ordenanzas sobre las vexaciones de los yndios asi de los alcaides mayores como de los relixiogos". ${ }^{47}$ Esse conjunto de normas proibia a utilização compulsória de serviços pessoais, a não ser que fossem necessários em casos de doutrina ou justiça, o que não atendeu aos anseios do bispo, que pregava a abolição completa dos serviços pessoais.

Durante a embaixada em Madri, Domingo de Salazar sofreu uma série de revezes, também contrários aos interesses das ordens religiosas. O Conselho das Índias determinou que até mesmo indígenas que não recebessem cuidado espiritual e temporal deveriam pagar tributos, medida duramente criticada pelo corpo eclesiástico atuante no arquipélago, com exceção dos jesuítas. Outro ponto foi que a fundação de novas igrejas e casas religiosas passou a depender, além da autorização episcopal, do beneplácito do governador do arquipélago. Este também seria

\footnotetext{
46 AGI, Copia de carta de G. P. Mariñas quejándose del obispo Filipinas, 18 b, r. 1, 3, img. 7.

${ }^{47}$ HIDALGO NÚCHERA, 1995, p. 238.
} 
responsável pela apresentação de nomes de eclesiásticos para as dignidades, canongías e prebendas. $^{48}$

$\mathrm{Na}$ estrutura eclesiástica, o Conselho das Índias anunciou uma mudança significativa. Manila foi elevada à condição de arcebispado. Junto a isso foram criados três dioceses nas ilhas: Cárceres (em Camarines), Nueva Segovia (em Cagayan) e Santíssimo Nome de Jesus (em Cebu). A incumbência destes bispos, em regiões afastadas de Manila (onde as missões e doctrinas avançavam) era para que exercessem "los actos pontificales" ${ }^{49}$ Esses prelados não possuiriam um governo episcopal propriamente dito: sem igreja catedral, sem dignidades e sem canongías. A orientação aos bispos é que atuassem "privadamente en el monesterio de buestra orden".

Domingo de Salazar, no entanto, não retornou às Filipinas para assumir o cargo de arcebispo. Faleceu na Europa em 1595. O fim de seu governo episcopal e as mudanças na estrutura eclesiástica das ilhas marcaram o início de um novo período na história, não só da cristianização, mas da própria colonização hispânica no arquipélago oriental.

\section{ÉPOCA DE VACÂNCIAS (1595-1617): REGALISMO E REFORMAS DO CLERO REGULAR}

Após um longo primeiro governo episcopal, os anos que sucederam a administração de Salazar se destacam por longas vacâncias na sede metropolitana de Manila. Segundo Manuela Águeda García-Garrido, essa fase foi um período conturbado no estabelecimento do modelo eclesiástico tridentino no arquipélago. A ausência do principal prelado nas ilhas teria intensificado situações de autonomia, insubmissão e corrupção dos membros do clero regular nas Filipinas, impedindo a padronização clerical e doutrinal pretendida por Trento. ${ }^{50}$ Os bispos sufragâneos, por estarem imersos no cotidiano de suas ordens, não teriam poder e interesse em agir a favor da Reforma Católica. Em suma, o fim do governo do bispo Domingo de Salazar teria instaurado duas décadas em que a frailocracia vigorou francamente.

\footnotetext{
48 AGI, Registro de ofício y partes de disposiciones reales, Filipinas, 339, L. 2, img. 120-127.

${ }^{49}$ AGI, Registro de ofício y partes de disposiciones reales, Filipinas, 339, L. 2, img. 294.

${ }^{50}$ GARCÍA-GARRIDO, 2015.
} 
O que observo para o período em questão não é uma simples oposição às reformas tridentinas e a ampliação das liberdades do clero regular. Em vez de uma frailocracia evidenciase a ascensão de uma hegemonia regalista nos discursos eclesiásticos no arquipélago. Como já dito, a partir de então, os presidentes da Audiencia de Manila passaram a ter mais influência na organização eclesiástica. A distribuição de prebendas e a definição geográfica das ordens passariam também pelo beneplácito do governante secular. Com o falecimento do arcebispo Ignacio de Santibañez em menos de quatro meses de governo ${ }^{51}$, o presidente Francisco de Tello tornou-se um dos principais personagens da vida eclesiástica das Filipinas. ${ }^{52} \mathrm{O}$ cabildo eclesiástico informou que a partir de então a Audiencia passou a exercer grande autoridade sobre o clero no exercício da justiça eclesiástica, bem como precedência em cerimônias públicas. O presidente Tello foi criticado por mover causas contra presbíteros e autorizar a abertura de muitas casas agostinianas e franciscanas, sem o beneplácito de arcebispo - então ausente - "conforme el patronazgo real". 53

Essa nova conformação gerou impacto imediato no discurso dos freis. Se antes os religiosos e clérigos denunciavam que as autoridades seculares (governador, alcaides, oficiais da Caja Real) tomavam atitudes contrárias ao direito natural e ao direito das gentes, a partir de meados da década de 1590, a principal reclamação é que as cédulas e ordenanças régias não eram cumpridas. ${ }^{54} \mathrm{O}$ governo das consciências continuou sendo referência na atuação dos freis, bispos e padres que das Filipinas. Exemplo disso é a atuação das ordens religiosas em uma questão extremamente importante na história hispânica no arquipélago, o comércio entre Manila e a Nova Espanha.

Em 1595 (já em sede vacante), os priores das quatro ordens religiosas (agostinianos, dominicanos, franciscanos e jesuítas) se reuniram para escrever um informe sobre o estado daquela república, argumentando que tinham "obligaçion de nra. parte de dar aviso a V mag.d

\footnotetext{
${ }^{51}$ Ignacio de Santibañez era frei franciscano, foi nomeado em 1595. Antes de passar ao arquipélago, Santibañez passou uma longa temporada na Nova Espanha, chegando a Manila apenas em 1598. AGI, Carta do cabildo eclesiástico, Filipinas, 77, 9.

${ }^{52}$ AGI, Registro de ofício y partes de disposiciones reales, Filipinas, 339, L. 2, img. 103; AGI, Carta de Tello sobre religiosos y sus necesidades, Filipinas, 18 b, 8, 106.

${ }_{53}$ AGI, Carta do cabildo eclesiástico, Filipinas, 77, 9, img. 3.

${ }^{54}$ AGI, Carta do cabildo eclesiástico sobre o comercio de Filipinas com Nova Espanha, Filipinas, 77, 6; AGI, Carta del obispo de Nueva Segovia, Miguel de Benavides, sobre quejas de los chinos, Filipinas, 76, 41; AGI, Carta de Ignacion de Santíbañez quejándose de Tello, Filipinas, 74, 42; AGI, Carta del dominico Juan de San Pedro Mártir sobre los chinos, Filipinas, 79, 32.
} 
de lo que tiene necesidad de remedio". 55 Deixavam claro que os temas tratados na carta eram da alçada temporal, mas cuja resolução garantiria que a atividade missionária prosseguisse e aumentasse, pois "es claro que faltando lo temporal ha de faltar lo spiritual a que todos atendemos".

Para atender aos pedidos saídos das Filipinas, o Conselho das Índias decretou que apenas vecinos de Manila e outras cidades do arquipélago poderiam participar do comércio entre a região e Acapulco. Dessa forma, comerciantes da Nova Espanha e do Peru estariam excluídos. Porém o cabildo eclesiástico reclamou que tal medida não era cumprida pelo governador. Os eclesiásticos sugeriam que o único modo de fazer com que aquela norma fosse devidamente aplicada era a imposição de censuras eclesiásticas, "q obligue en cõscientia o descomunion a q se guarde lo q v. mag.t tã justamente manda". ${ }^{56}$ A ideia era exercer o governo das consciências para que a vontade do monarca fosse aplicada, mas, neste caso, apenas autorizados pelo Conselho das Índias.

A maior influência secular sobre a organização eclesiástica fez com que questões da potestade temporal se tornassem de interesse e preocupação por parte de padres, freis e cônegos. Ao mesmo tempo, a atuação das autoridades seculares passou a ser mais discutida e vigiada pela Igreja.

Na mesma época que o cabildo eclesiástico escrevia ao Conselho, o frei dominicano Diego de Soria predicou um sermão no qual dizia que os criados do governador não poderiam ter ofícios no arquipélago, "por ser cossa q v. mag.d por su real cedula tiene vedada". ${ }^{57} \mathrm{De}$ acordo com o frei, sua intenção era defender os interesses do rei. O não cumprimento das ordenanças régias era pecado, nos dizeres do frei. Na mesma missiva, o frei Soria informou que ordenou pena de excomunhão àqueles que traficavam, prejudicando a Real Hacienda ${ }^{58}$

As ações de padres e freis contra o governador ou outras autoridades seculares não ocorriam por serem independentes e livres, mas justamente pela sua obediência ao poder monárquico espanhol. Pode-se argumentar que isso seria um mecanismo discursivo das

\footnotetext{
${ }^{55}$ AGI, Carta de las órdenes religiosas sobre estado de las Filipinas, Filipinas, 79, 27, img. 1.

${ }^{56}$ AGI, Carta de las órdenes religiosas sobre estado de las Filipinas, Filipinas, 79, 27, img. 1.

${ }^{57}$ AGI, Carta del cabildo eclesiástico denunciando persecución de fray Diego de Soria, Filipinas, 84, 75

58 AGI, Cartas del dominicano Diego de Soria sobre su persecución, Filipinas, 84, 76, img. 5.
} 
religiões e cabildo eclesiástico para justificar suas atitudes e oposição ao governador. No entanto, é significativa a introdução desse elemento - inexistente ou secundário nas três primeiras décadas de colonização - no discurso eclesiástico.

Exemplo marcante é uma ordem régia, recebida no arquipélago nos anos finais da década de 1590. O rei espanhol declarou que o que havia sido feito em relação aos nativos por força e por medo tornasse a ser feito, mas por meios suaves e amorosos. Os indígenas deveriam dar sua obediência ao rei de Castela livremente e com gosto. ${ }^{59}$ Após a realização de uma junta, chefiada pelo arcebispo Santibañez, com a presença dos bispos sufragâneos e dos prelados das ordens religiosas, os eclesiásticos passaram a executar a vontade da cédula.

Nas pregações aos nativos, membros do clero regular pediam perdão pelos agravos cometidos e rogavam sua livre submissão ao rei de Castela. Segundo o bispo de Nueva Segovia, Miguel de Benavides, os nativos aceitavam os pedidos e gostavam do que ouviam, dando voluntariamente sua obediência. Além disso, "perdonaron tambien los tributos que siendo infieles les cobren y an cobrado". ${ }^{60}$ Frei Benavides enviou ao Conselho das Índias uma ata na qual vários chefes indígenas, tanto cristãos quanto infiéis, afirmavam sua vassalagem ao monarca espanhol. É significativo observar membros do clero se valendo de espaços religiosos em prol dos interesses régios, atuando como liderança agregadora em nome do rei, que incluía os nativos na Monarquía.

As críticas aos costumes e às práticas do governador Francisco Tello ocupam diversas linhas das cartas encaminhadas ao Conselho das Índias. O frei Miguel Benavides afirmou que "es cosa de sathanas el ser governador este desventurado honbre". ${ }^{61} \mathrm{O}$ também dominicano Bernardo de Santa Catalina declarou que todos em Manila ficavam escandalizados com sua falta de moralidade, pois não tinha esposa e tinha uma vida marcada pela luxúria e jogos. Assim, as ordens religiosas se reuniram em junta "y se determino [que] estava obligado a casarse" ${ }^{62} \mathrm{O}$ casamento não diminuiu as denúncias contra o presidente da Audiencia. Tello acabou sendo excomungado, acusado de simonia, por ter oferecido correntes de ouro e dinheiro para que as

${ }^{59}$ AGI, Carta del obispo de Nueva Segovia, Miguel de Benavides, sobre conversión y vasallaje de los naturales, Filipinas, $76,44$.

${ }^{60}$ AGI, Carta del obispo de Nueva Segovia, Miguel de Benavides, sobre conversión y vasallaje de los naturales, Filipinas, 76, 44, img. 1

${ }^{61}$ AGI, Carta del obispo de Nueva Segovia, Miguel de Benavides, informando del estado de las islas, Filipinas, 76, 39, img. 2.

${ }^{62}$ AGI, Carta del dominico Bernardo de Santa Catalina denunciando el governador de las Filipinas, Filipinas, 84, 83, img. 1. 
pessoas por ele apresentadas para assumir dignidades e canongías fossem confirmadas pelo arcebispo. ${ }^{63}$

Ao se defender das críticas oriundas do corpo eclesiástico, o presidente Francisco de Tello propôs que todas as ordens religiosas e instituições clericais (como o cabildo) fossem visitadas, isto é, inspecionadas por um superior da própria organização a fim de avaliar, revisar e corrigir. As visitas eram instrumentos pastorais e de exercício jurisdicional instituídos pelo Concílio de Trento, a fim de garantir a execução da reforma moral do clero. Tal pedido não surgia apenas do lado da Audiencia. O bispo frei Miguel de Benavides escreveu, em 1599, que havia muitas irregularidades nas ordens, que urgiam por correção. ${ }^{64}$ Mesmo num contexto de sede vacante do arcebispado, um dos principais temas tridentinos dominou o debate religioso: a reforma da disciplina do clero.

Essa série de críticas e denúncias significariam, a princípio, sinais da frailocracia. Denúncias de liberdade e insubmissão derivavam de vários lados, dando a entender que não eram denúncias vazias e completamente falsas. No entanto, considero que o número elevado de reclamações, partindo de instituições diferentes - temporais e religiosas - também indica que a reforma do clero era preocupação e atitude presente nas ilhas Filipinas.

Ainda em 1599, o governador Tello escreveu ao Conselho das Índias informando que uma visita aos franciscanos acabava de ser finalizada, e que as notícias não eram boas. Os inacianos se encontravam em visita no momento da escrita daquele informe. Em relação a dominicanos e agostinianos, o presidente da Audiencia recomendou que ambas as religiões passassem por severa averiguação. Tello preferiu não entrar em detalhes sobre o que se passava, mas destacou que "lo mas entiendo toca en daño de mugeres". ${ }^{65} \mathrm{O}$ informe de António de Morga, que abre este artigo, foi escrito no mesmo contexto, questionando a qualidade moral do clero atuante nas ilhas. O cabildo eclesiástico, encabeçado pelo vigário-geral Juan de Vivero, pediu uma visita geral ao arquipélago, pois "los naturales van perdiendo la deboçion”. A crítica do cabildo se voltava principalmente à ordem de Santo Agostinho e era reforçada por outras

\footnotetext{
${ }^{63}$ AGI, Carta del dominico Bernardo de Santa Catalina denunciando el governador de las Filipinas, Filipinas, 84, 83, img. 2 ${ }^{64}$ AGI, Carta del obispo de Nueva Segovia, Miguel de Benavides, denunciando la situación de Filipinas, Filipinas, 76, 42.

${ }^{65}$ AGI, Carta de Tello sobre arzobispo y religiosos, Filipinas, 6, 9, 169, img. 3.
} 
autoridades religiosas, como o bispo Miguel de Benavides, que reclamava da fraca evangelização nas áreas sob cuidado dos agostinianos.

Denúncias contra os agostinianos também partiram de dentro da própria ordem. Em 1597, o frei Alonso Vico denunciou que seus colegas reuniam grandes rendas, às custas da exploração dos nativos. Os priores tomavam todo dinheiro para si e para seus parentes. Boa parte dos religiosos era relapsa com suas atividades eclesiásticas, não ministrando missas e sacramentos como deveriam. Tudo aquilo ocorria com grande publicidade e liberdade. Sua ordem estaria contaminada por vícios variados como a ganância e outros que, segundo Vico, eram indizíveis. A origem desses problemas, afirmou, era " $q$ esta pvincia esta tan apoderada de criollos". 66

A disputa entre criollos e peninsulares foi uma questão presente em diversas ordens religiosas no Ultramar. Frei Vico destacou que a província agostiniana da Nova Espanha passava pelo mesmo problema. A ascensão dessas rivalidades faz parte de um processo mais amplo de afirmação do modelo urbano de colonização que se refletiu no aumento dos ingressos de membros nas ordens religiosas, a partir da década de $1570 .{ }^{67}$

Frei Alonso de Vico denunciou seu colega Lorenzo de León como um dos principais causadores de problemas. ${ }^{68}$ De León foi acusado de manipular a seu favor a eleição para provincial, facilitando o início de medidas que favoreciam aos criollos na província do Santíssimo Nome de Jesus. Dominicanos e o arcebispo Ignacio de Santibañez foram outros a criticar duramente frei Lorenzo de León. ${ }^{69}$ Em 1599, o bispo de Cebu, frei Pedro Agurto, ao pedir mais ministros para atuar na sua diocese recomendou que fossem dominicanos, franciscanos e jesuítas, pois estes "an procedido y proceden con mas observancia"70, comparados aos freis de Santo Agostinho, ordem a qual pertencia o próprio bispo Agurto. Naquele mesmo ano, o cabildo eclesiástico pediu a indicação mais breve possível de novo arcebispo para a região, desde "que en ninguna manera venga religioso de la orden de S.

\footnotetext{
${ }^{66}$ AGI, Carta del agustino Alonso de Vico sobre reforma de los agustinos, Filipinas, 84, 78, img. 2.

${ }^{67}$ MELVIN, Karen. Building colonial cities of God. Mendicant orders and urban culture in New Spain. Stanford: Stanford University Press, 2012 , p. $46-54$

${ }^{68}$ Frei Lorenzo de León era natural de Granada, mas assumiu o hábito agostiniano no México, em 1578, por isso é considerado da ala criolla AGI, Carta del agustino Lorenzo de León sobre falta de religiosos, Filipinas, 84, 67.

${ }^{69}$ AGI, Carta de dominicos a Miguel de Benavides o al procurador en la corte, Filipinas, 84, 66, img. 7; AGI, Registro de oficio de la Audiencia de Filipinas, Filipinas, 329, 1. 1, f. 11r.

${ }^{70}$ AGI, Carta del obispo de Cebú, Pedro de Agurto, sobre varios asuntos, Filipinas, 76, 3, img. 5.
} 
Augustin, en casi todos notados de codiçia" ${ }^{71} \mathrm{O}$ temor é que frei Lorenzo de León, que havia encerrado seu governo provincial, fosse nomeado para o posto.

Em 1602, frei Pedro Arce foi eleito provincial agostiniano prometendo consertar tudo "lo que tubiere necessidad de reformacion". ${ }^{72}$ Um ano depois, o otimismo havia sumido. Arce e seus colegas peninsulares escreveram uma carta na qual suplicavam a intervenção régia na ordem, pois era urgente a reforma daquela província, pois muitos freis "biben en la ley que a cada uno mejor le parece" ${ }^{73}$ Dominicanos, franciscanos e cabildo eclesiástico se somaram ao grupo peninsular, pedindo o envio de mais freis de Santo Agostinho oriundos da Espanha, incluindo um visitador. ${ }^{74}$

Em meio a tantas denúncias, frei Lorenzo de León foi novamente eleito provincial, em 1605. Tal fato acirrou de vez as tensões entre peninsulares e criollos. Uma carta assinada por 14 daqueles, denunciou que o governo de frei de León beneficiava "religiosos moços indoctos distraídos y de poco caudal". ${ }^{75}$ Frei Juan de Tapia foi além, qualificando os membros da ala criolla de "ydiotas apassionados y de inclinaçiones muy abiesas". ${ }^{76}$ As súplicas se dirigiam ao monarca, pelo Conselho das Índias. Por mais que fosse uma questão interna da ordem de Santo Agostinho, os problemas atingiam as ilhas como um todo, o que justificava a intervenção do poder régio na questão.

Frei Miguel de Benavides assumiu como arcebispo de Manila, no ano de 1603. Logo elevou seu tom para pedir visita aos agostinianos e contra frei Lorenzo de León. ${ }^{77} \mathrm{O}$ novo arcebispo, porém, não pode fazer muito, pois faleceu pouco tempo depois da nova eleição de frei de León como provincial. Este não perdeu tempo, logo escreveu - em nome de sua ordem - ao Conselho das Índias, recomendando a si mesmo para o governo da igreja metropolitana de Manila. ${ }^{78}$

\footnotetext{
${ }^{71}$ AGI, Carta do cabildo eclesiástico, Filipinas, 77, 9, img. 1.

72 AGI, Carta de los agustinos de Manila sobre visita de fray Pedro de Sosa, Filipinas, 84, 103, img. 1.

${ }^{73}$ AGI, Carta de los agustinos pidiendo que se visite su orden, Filipinas, 84, 143, img. 1.

${ }^{74}$ AGI, Carta de dominicos en favor de los agustinos, Filipinas, 84, 121; AGI, Carta del franciscano Juan de Garrovillas en favor de los agustinos de Filipinas, Filipinas, 84, 123; AGI, Carta del cabildo eclesiástico de Manila sobre varios asuntos, Filipinas, 84, 128.

75 AGI, Carta de los agustinos contra fray Lorenzo de León, Filipinas, 79, 52, img. 3.

${ }^{76}$ AGI, Carta del agustino Juan de Tapia sobre reforma de los agustinos, Filipinas, 84, 135, img. 1.

${ }_{77}$ AGI, Registro de oficio de la Audiencia de Filipinas, Filipinas, 329, 1. 2, fls. 29

78 AGI, Carta de agustinos de Manila sobre varios asuntos, Filipinas, 79, 59
} 
Os intentos do provincial, porém, foram frustrados. Ações do Conselho das Índias minaram as forças do partido criollo dentro da ordem de Santo Agostinho. Em 1606, a província agostiniana recebeu vários freis do ramo recoleto, visando reformar aquela casa. No ano seguinte foi a vez de frei Pedro de Solier, da ala peninsular, chegar da Espanha acompanhado de vários freis. ${ }^{79}$ Solier teve amplos poderes e orientações para executar a pedida reforma da ordem, logo assumindo o posto de provincial. O cabildo da cidade de Manila comemorou a chegada do novo frei. ${ }^{80} \mathrm{O}$ jesuíta Gregório López e o governador Rodrigo de Vivero foram outros a exaltar a reforma promovida por Solier. ${ }^{81}$

\section{A ATUACÃo do santo ofício e a perseguicão aO delito de SOLICITACÃO}

O cerco se fechou também por outros lados. O Santo Ofício foi um dos principais mecanismos de atuação para promover o controle dos agostinianos. Como já vimos, o tribunal inquisitorial atuava no arquipélago por seus de comissários desde a década de 1580, no entanto, marcado por uma atuação muito tímida em seus primeiros 20 anos. ${ }^{82}$ No início do século XVII, os comissários das Filipinas mudam de postura, atentando para delitos relativos à moral pública e que causavam grave escândalo: as blasfêmias e a solicitação em confissão.

A ênfase dada pelos comissários filipinos ao delito de solicitação se deveu a uma confluência de motivos. Primeiro, a própria visão do Santo Ofício sobre o tema, que se constituiu como herético entre o fim do século XVI e início do XVII, visando defender o modelo sacramental tridentino e estabelecer um controle externo aos confessores, subordinando a confissão à Inquisição. ${ }^{83}$

A primeira postura oficial do Santo Ofício em relação à prática de solicitação foi em 1559, com a autorização do papa Paulo IV ao inquisidor de Granada para tratar do ocorrido como delito de alçada inquisitorial. Em 1561, o sumo pontífice estendeu a autoridade dessa bula

\footnotetext{
${ }^{79}$ AGI, Relación de agustinos que pasan con fray Pedro de Solier, Filipinas, 79, 56.

${ }^{80}$ AGI, Carta del cabildo secular de Manila sobre estado de las islas, Filipinas, 36, 39.

${ }^{81}$ AGI, Carta del jesuíta Gregorio López sobre estado de Filipinas, Filipinas, 79, 64, img. 2; AGI, Petición del agustino Tomás Márquez de varias mercedes, Filipinas, 79, 117, img. 5.

${ }^{82}$ PALANCO, 2018.

${ }^{83}$ HALICZER, Stephen. Sexualidad en el confesionario. Un sacramento profanado. Madri: Siglo XXI, 1998; PROSPERI, 2013 , p. 501.
} 
(Contra Sollicitantes) a todos os tribunais da Monarquía espanhola. A definitiva inclusão da solicitação nos éditos de fé se fez em 1576, na categoria "heresias diversas". No mesmo ano, o Conselho de Inquisição produziu uma instrução aos inquisidores de Lima e do México.

Em fevereiro de 1598, os inquisidores da Nova Espanha enviaram uma carta ao comissário em Manila, frei Juan Maldonado. No documento, os inquisidores instruem o comissário que "en lo q toca a los solicitantes guardara lo q el edito de la fe dispone y las testificaciones q reciviere en q no aya mas de un testigo la enviara al Sto offo.". ${ }^{84}$ Essa orientação indica como esse tipo de situação não deveria ser incomum, mas até então não tratadas em âmbito inquisitorial. Em 1599, um dos inquisidores mexicanos enviou outro informe, reforçando o quanto o tribunal do Santo Ofício se tinha por mal servido que ministros da penitência solicitassem seus confitentes. A partir deste último informe, os comissários de Manila entraram em contato com os prelados das religiões e com o cabildo eclesiástico, para falar da obrigação que tinham os confessores "a no absolver a las solicitadas en cõfesion asta denunciar en el santo officio de los solicitantes". 85

Segundo motivo. Essa informação surge no mesmo contexto no qual as denúncias de desvio moral do clero (regular e secular) das Filipinas começaram a pulular. Nesse contexto, se dá também o fim do monopólio agostiniano sobre o Santo Ofício nas ilhas. Frei Juan Maldonado era um predicador. A rivalidade entre dominicanos e agostinianos nas Filipinas, desde a década de 1580, e especialmente as denúncias de corrupção moral, com franca oposição dominicana, que dominava a comisaría da Inquisição, à ala criolla da província agostiniana, estimularam a ação daqueles sobre os discípulos do bispo de Hipona.

Associado a isso, está o terceiro motivo, o qual chamo mais a atenção. As denúncias de solicitação tornam-se constantes e muito numerosas justamente a partir da vacância do arcebispado de Manila, com a morte de Miguel de Benavides, em 1605. Os dominicanos, liderados por seu provincial, frei Bernardo de Santa Catalina (também comissário do Santo Ofício), utilizaram da instituição inquisitorial para, se não promover a tão pedida reforma do

${ }^{84}$ AGN, Inquisición, v. 223.

${ }^{85}$ AGN, Oficio de recibo de la noticia de 35 testificaciones para solicitantes en el Santo Oficio, Indiferente Virreinal, c. 2660, exp. 11, img. 01 . 
clero atuante nas Filipinas, controlar e limitar os desvios morais cometidos por uma parcela dos eclesiásticos.

O principal caso é do mestre-escola Luis de Salinas, figura que por vários anos ocupou funções no cabildo eclesiástico, envolvendo-se em diversas querelas com seus colegas. ${ }^{86}$ Salinas foi denunciado diversas vezes pelo delito de solicitação. Além disso, também foi denunciado ao Santo Ofício por "palavras malsoantes" e "por ter dito missa depois de ter comido" ${ }^{87}$ Antes de sua morte, o arcebispo Benavides chegou a visitar o curato do mestreescola, em Balayan, evidenciando vários problemas, alguns de alçada inquisitorial. ${ }^{88}$ Em visita à doctrina de Salinas, o frei Santa Catalina constatou que padre não dizia missa havia 14 meses, dentre outros problemas. ${ }^{89}$

Porém, o provincial dos freis pregadores não era apenas crítico. O comissário relatou que os nativos de Balayan davam graças aos céus, que antes de Salinas, eles haviam sido evangelizados por franciscanos descalços, pois se tivessem sido introduzido na fé pelo mestreescola não acreditariam em deus. Assim, os relatos e as informações dos freis dominicanos que atuavam pelo Santo Ofício não eram apenas a descrição de um quadro caótico de indisciplina geral do clero, mas delimitavam a linha que separava os bons dos maus religiosos. Ao mesmo tempo, clamando para eles predicadores e comissários um papel de preeminência na correção e vigilância sobre o clero local.

O caso do frei agostiniano Francisco de Santa Maria é exemplar. Com mais de 20 testemunhos corroborando a acusação de solicitação ${ }^{90}$, entre 1606 e 1609 . O frei foi descrito pelo comissário Francisco de Herrera (dominicano), como idiota e escandaloso, que todos sabiam que ele solicitava às índias em confissão. Ao lado de seu nome em uma das várias relações de causa em que foi arrolado constam os seguintes dizeres: "Es frayle idiota tomo el habito aqui en philipinas". ${ }^{91}$ Como vimos anteriormente, muitos creditavam a má qualidade do

\footnotetext{
${ }^{86}$ AGI, Carta del maestreescuela Luis de Salinas sobre denuncias que ha hecho, Filipinas, 84, 150; AGI, Carta de Tello sobre presentaciones de la Catedral, Filipinas, 19, 3, 50.

${ }^{87}$ AGN, Relación de las causas del año de 1605, por fray Bernardo de Santa Catalina, Indiferente Virreinal, c. 2660, exp. 15; AGN, Relación de las denuncias hechas antes la Inquisición, Indiferente Virreinal, c. 4154, exp. 26, img. 2; AGN, Relación de los navios que zarparon a la Nueva España desde Manila en el año de 1604, Indiferente Virreinal, c. 2660, exp. 16.

${ }^{88}$ AGN, Correspondencia del comisario del Santo Oficio de Manila, fray Bernardo de Santa Catalina, Indiferente Virreinal, c. 5172 , exp. 85.

${ }^{89}$ AGI, Carta del dominico Bernardo de Santa Catalina sobre varios asuntos, Filipinas, 79, 73, img. 3.

${ }^{90} \mathrm{AGN}$, Relación de la comisaría del arzobispado de Manila desde la partida de los navios de 1607, Indiferente Virreinal, c. 2660, exp. 12.

${ }^{91}$ AGN, Memoria de testificaciones que se envian a la Santa Inquisición de México por los años de 1608 y 1609, Indiferente Virreinal, c. 2660, exp. 31 .
} 
clero filipino ao fato de muitos serem criollos e, principalmente, terem se tornado religiosos no arquipélago, o que afligia especialmente a ordem agostiniana. A ação dominicana e inquisitorial fez questão de enfatizar isso.

Atendo-nos ao delito de solicitação, registramos ao menos 45 homens acusados de violar o sacramento da confissão.

\section{Gráfico 1. Denunciados à Inquisição pelo delito de solicitação, por classificação religiosa} (Filipinas, 1600-1610)

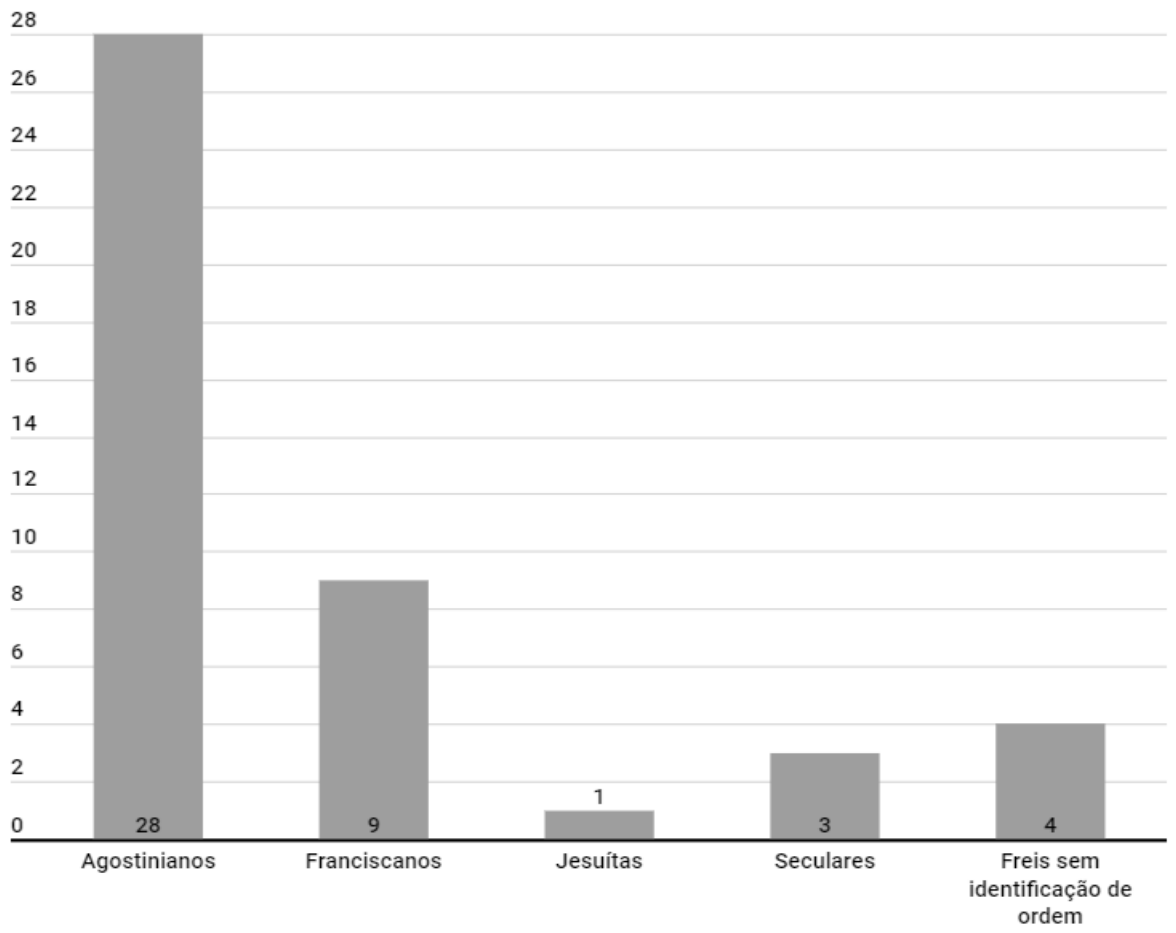

Fonte: AGN, Inquisión, v. 263, fl 340; AGN, Inquisión, v. 1494; AGN, Declaración contra Hernando Basques, religioso de la compañía de Jesús por haber tenido acceso carnal con una india, Indiferente Virreinal, c. 5596, exp. 11; AGN, Oficio de recibo de la noticia de 35 testificaciones para solicitantes en el Santo Oficio, Indiferente Virreinal, c. 2660, exp. 11; AGN, Relación de la comisaría del arzobispado de Manila desde la partida de los navios de 1607, Indiferente Virreinal, c. 2660, exp. 12; AGN, Relación de las causas del año de 1605, por fray Bernardo de Santa Catalina, Indiferente Virreinal c. 2660, exp. 15; AGN, Relación de los navios que zarparon a la Nueva España desde Manila en el año de 1604, Indiferente Virreinal, c. 2660, exp. 16; AGN, Memoria de testificaciones que se envian a la Santa Inquisición de México por los años de 1608 y 1609, Indiferente Virreinal, c. 2660, exp. 31; AGN, Denuncia hecha contra fray Lucas de Salas de la orden de San Agustín, por Agustina de Saen por haberle hecho solicitación, Indiferente Virreinal, c. 3436, exp. 28; AGN, Relación de denun cias hechas en la comisaría del arzobispado de Manila desde el año 1606 y 1607, Indiferente Virreinal,c. 3436, exp. 30; AGN, Cartas del fray Bernardo de Santa Catalina, comisario del Santo Oficio en Manila, Indiferente Virreinal, c. 3436, exp. 38; AGN, Denuncia con tra fray Diego Pardo por hacer solicitaciones después de haber santiguado, por una india llamada María Combocha, Indiferente Virreinal, c. 3436, exp. 42; AGN, Denuncia ante la Inquisición por María Sanayin contra el pároco del pueblo de Bulacan por querer cometer actos ilícitos con ella, Indiferente Virreinal, c. 4154, exp. 05; AGN, Denuncia ante la Inquisición contra fray Diego Negrete, Indiferente Virreinal, c. 4154, exp. 20; AGN, Denuncia de Ines Singo antes la Inquisición contra frailes franciscanos por cometer actos ilícitos con ella, Indiferente Virreinal, c. 4154, exp. 21; AGN, Relación de las denuncias hechas antes la Inquisición, Indiferente Virreinal, c. 4154, exp. 26; AGN, Petición de fray Francisco de Herrera de darle solución al problema de que frailes piden a indias presentarse a confesión para tener actos ilícitos con ellas, Indiferente Virreinal, c. 4154, exp. 35. Antes de 1600, o único caso de solicitação identificado na alçada inquisitorial, foi o movido pelo bispo Domingo de Salazar, em 1582, contra o presbítero Francisco de Pareja. 
Ainda identificamos casos não classificados como solicitação, mas que também incluem desvios sexuais do clero. O frei Cristoval de Fonseca, agostiniano, foi denunciado por "ter romance". ${ }^{92}$ Já o padre jesuíta Valerio de Ledesma foi denunciado por fazer com que o penitente declarasse "el apice" na confissão. ${ }^{93}$

Outro frei agostiniano denunciado ao Santo Ofício foi justamente o frei Lorenzo de León. Em 1605, foi acusado de ter dito em sermão que sua santidade era igual à de Santo Agostinho. Na mesma predica, declarou que jamais houve santo tão humilde quanto o bispo de Hipona, pelo que foi acusado de tentar igualar Agostinho aos apóstolos. ${ }^{94}$

\section{Gráfico 2. Denúncias de solicitação aos comissários de Manila, por ano (1600-1610)}

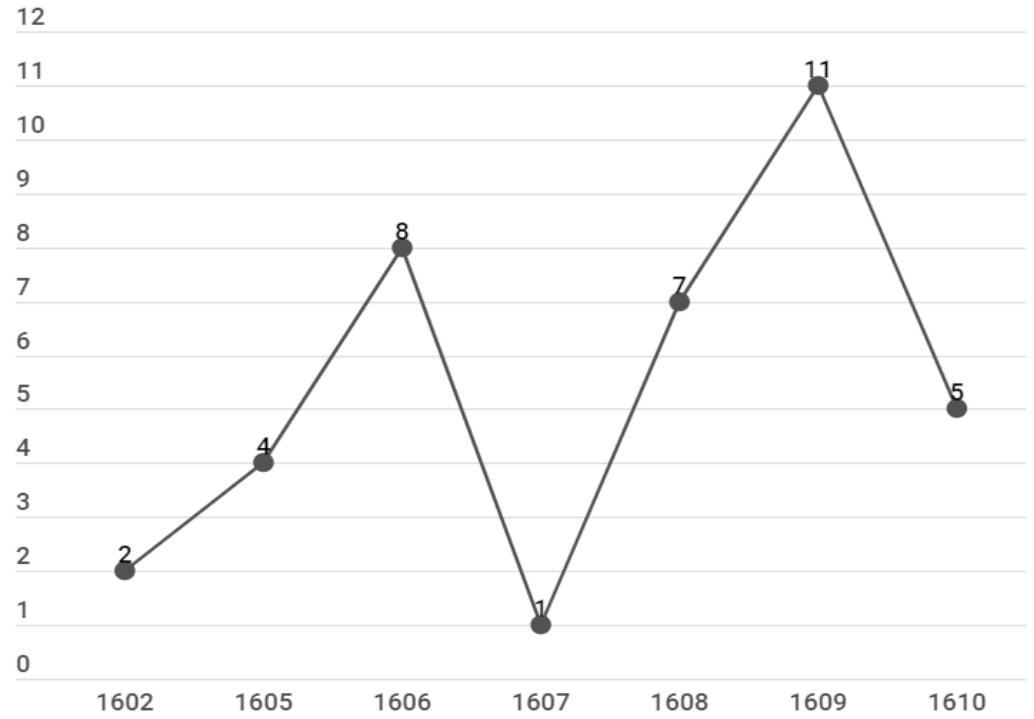

Fonte: Ver as referências do gráfico anterior. Alguns religiosos foram denunciados mais de uma vez.

Esses dados deixam claro, as causas sem concentram em um período - 1605 a 1610 -, e em um público: os freis agostinianos.

\footnotetext{
${ }^{92} \mathrm{AGN}$, Razón dada a la Inquisición sobre recibo de despachos sobre el capitán Pedro de Busto y Lucas de Mañozca; sobre un romance que tiene fray Cristóbal de Fonseca, agustino, Indiferente Virreinal, c. 4154, exp. 33.

${ }^{23}$ AGN, Relación de las denuncias hechas antes la Inquisición Indiferente Virreinal, c. 4154, exp. 26, img. 2.

${ }^{94} \mathrm{AGN}$, Relación de los navios que zarparon a la Nueva España desde Manila en el año de 1604, Indiferente Virreinal, c. 2660, exp. 16.
} 
Além do marcante caso do frei Santa Maria, outros casos por solicitação chamam a atenção, como frei Juan Amorim, um dos principais partidários de Lorenzo de León. As afirmações sobre os criollos de Santo Agostinho eram quase sempre as mesmas: cometiam delitos por terem fraca formação, tomando hábito religioso no arquipélago. Frei Bernardo de Santa Catalina escreveu sobre os solicitantes: "es gente q saben poco, no tratan de religion y ayer erã soldados" $" 95$.

Em uma lista com causas de solicitadores, foram arrolados 27 religiosos. Dez deles (incluindo Santa Maria) constavam com a indicação de que havia tomado hábito religioso nas Filipinas, todos agostinianos. Sobre um deles, Juan de Robles, o comissário comenta que ele foi frei leigo de São Domingos, mas foi expulso pelos predicadores, então ingressando na ordem agostiniana. O único a quem o comissário fez ressalva foi o frei agostiniano Juan Baptista de Montoya. Escreveu que dele ouvia-se falar bem e era pessoa de bom exemplo, considerado homem muito religioso. Diferente de seus colegas, ele havia passado para o arquipélago já como frei. Em seu comentário final, frei Bernardo de Santa Catalina reforçou seu pensamento: "por aca de ordinario los ministros son gete ydiota y por esta parte tratan de poca mortificacion y son tan señores de los pobres yndios". 96

Ao depor contra dois agostinianos solicitantes, a indígena Maria Linagin disse que estava muito feliz com os dominicanos "por no hallar en ellos que tachar pues en pidiendoles confession luego preguntan si avemos hecho memoria de nros. pecados y nos diçen no tengamos temor ni verguença", por outro lado "estos p.es de S.to agustin luego nos tratan de cosas muy outras y que dañan al alma y juegan con nosotras". ${ }^{97}$ Maria Sanayin disse ter sido solicitada em confissão por dois freis agostinianos. Nas duas ocasiões ela resistiu às investidas violentas dos religiosos. No entanto, a denúncia ocorreu apenas ela ter sido instruída por um confessor da ordem de São Domingos, que indicou que procurasse o comissário da Inquisição. ${ }^{98}$

\footnotetext{
${ }^{95}$ AGN, Oficio de recibo de la noticia de 35 testificaciones para solicitantes en el Santo Oficio, Indiferente Virreinal, c. 2660 , exp. 11 , img. 1. ${ }^{96}$ AGN, Oficio de recibo de la noticia de 35 testificaciones para solicitantes en el Santo Oficio Indiferente Virreinal, c. 2660, exp. 11 , img. 1. ${ }^{97}$ AGN, Denuncia ante la Inquisición por María Sanayin contra el pároco del pueblo de Bulacan por querer cometer actos ilícitos con ella, Indiferente Virreinal, c. 4154, exp. 5, img. 3.

${ }^{98}$ AGN, Denuncia ante la Inquisición por María Sanayin contra el pároco del pueblo de Bulacan por querer cometer actos ilícitos con ella Indiferente Virreinal, c. 4154, exp. 5.
} 
Foram tantos os casos, que por pedido do inquisidor do México, o Conselho de Inquisição permitiu que processos de solicitação das Filipinas fossem julgados no próprio arquipélago, pelos comissários acompanhados de "oidor o persona calificada". ${ }^{99}$ Nesse mesmo contexto, os peninsulares da ordem de Santo Agostinho conseguiram que, em 1609, frei Diego de Guevara, procurador da ordem na corte, retornasse às ilhas orientais com a patente de visitador, "para vissitar y reformar la provincia de las philippinas". ${ }^{100}$

\section{CONCLUSÃO: A REFORMA AGOSTINIANA NA DÉCADA 1610 E CONFESSIONALIZACÃO CATÓLICA NAS FILIPINAS}

A partir da segunda década do século XVII, os informes sobre a ordem agostiniana nas Filipinas passaram a ser positivos. A Audiencia afirmou que a província daquela religião estava "en gran perfection y que acudia com puntualidad a las cossas del serviçio de dios". ${ }^{101}$ Os franciscanos descalços, o governador Juan de Silva, o cabildo secular de Manila, o arcebispo Diego Vázquez e os oficiais da Real Hacienda também elogiaram a visita e a reforma realizada entre os seguidores de Santo Agostinho. ${ }^{102} \mathrm{Na}$ década de 1610, há um evidente ocaso das críticas à ordem agostiniana, seja nos aspectos morais ou políticos. Sobre as demais ordens também, quase nada se vê em matéria de oposição à sua atuação, seja por parte das autoridades seculares ou eclesiásticas. Até mesmo os dominicanos, que durante quase 30 anos disputaram espaço com os freis de Santo Agostinho, apresentavam uma nova visão sobre seus companheiros de missão. ${ }^{103}$

Nas décadas seguintes, os peninsulares dominaram a província agostiniana. Sem o mesmo poder de antes, os criollos tomaram atitudes extremas, como o assassinato do provincial Vicente de Sepúlveda, por quatro freis opositores, em 1617. ${ }^{104}$ Esse evento, no entanto, só agravou a situação dos criollos. Mesmo com orientações régias e pontifícias para adotar um modelo de alternância - destinado a todas as possessões ultramarinas - os freis espanhóis

\footnotetext{
99 TORIBIO MEDINA, José. El tribunal del Santo Oficio de la Inquisición en las islas Filipinas. Santiago: Imprenta Elzeviriana: 1899 , p. 39. ${ }^{100}$ AGI, Petición del agustino Diego de Guevara sobre viaje a Filipinas y despachos de religiosos, Filipinas, 79, 84, im.g 1.

${ }^{101}$ AGI, Carta de la Audiencia de Manila sobre necesidad de monasterio de monjas, Filipinas, 20, 6, 47.

${ }^{102}$ AGI, Carta de franciscanos sobre mal estado de las Filipinas, Filipinas, 85, 24; AGI, Recomendación de Silva para que se de obispado a Salas, Filipinas, 7, 4, 50; AGI, Petición del agustino Miguel García de licencia para 50 religiosos, Filipinas, 85, 26.

${ }^{103}$ AGI, Carta del dominico Miguel de San Jacinto sobre agravios a indios y otros asuntos, Filipinas, 85, 25, img. 1.

${ }^{104}$ AGI, Carta de Alvarado sobre muertes de dela Vega y Sepulveda, Filipinas, 20, 11, 71.
} 
impediram o acesso de criollos aos cargos de governo, argumentando que estes seriam daninhos para aquela religião. Esse domínio se refletiu também na demografia da ordem, composta em sua grande maioria por freis que tomaram hábito na Espanha. Para se manter no controle, os peninsulares tiveram duros enfrentamentos. Além dos criollos, encomenderos, governadores e autoridades arquiepiscopais, por vezes tentaram, sem sucesso, acabar com tal monopólio. ${ }^{105}$

O processo, aqui descrito, mostra como as Filipinas não ficaram alheias à confessionalização promovida pela Igreja católica. Isso não quer dizer que as ordens religiosas deixaram de se envolver em querelas e disputas, tanto com autoridades eclesiásticas quanto seculares. No entanto, vemos que princípios, práticas e instituições tridentinas não foram estranhas à história eclesiástica das Filipinas. Mesmo com longas vacâncias de arcebispos observamos ações de disciplinarização das consciências dos fiéis e de controle sobre o clero. Por caminhos distintos e dentro da sua especificidade, a reforma católica gerou resultados práticos na vida religiosa do arquipélago asiático. Isto é, não era uma exceção ou um governo eclesiástico ímpar, a chamada frailocracia.

O clero regular foi muito influente e atuante em toda história colonial das Filipinas. Essa atuação, no entanto, não pode ser resumida à intromissão ou à corrupção. Quando um frei agia, o fazia alegando exercer a justiça. ${ }^{106}$ Nestas situações acionavam discursos de obediência e ordem, dizendo agir de acordo com o Patronato Real e o direito canônico. Insubmissão ocorria aos olhos dos alcaides, governadores e ouvidores da Audiencia, que ficavam alheios. O contrário também pode ser dito. Quando um juiz secular prendia ou castigava um nativo, por conta de um processo do âmbito religioso ou de foro misto, ele era abusivo e intrometido do ponto de vista eclesiástico, mas não do braço temporal atuante no arquipélago.

Durante o século XVII os registros de situações de conflito entre os religiosos e os arcebispos de Manila prosseguiram, especialmente no que tangia a imposição da autoridade

\footnotetext{
${ }^{105}$ GARCÍA-GARRIDO, Manuela. Peticiones contra el 'breve de la alternativa' o el rechazo de la hibridacion clerical en Filipinas. [em linha], E-Spania, n. 30, 2018

${ }^{106}$ Como destaca Alejandro Cañeque, um dos principais erros ao analisar a relação entre os corpos eclesiásticos e os poderes políticos na América Hispânica é partir da concepção de "Estado". Desta forma se enxerga uma tendência absolutista, na qual o governo político progressivamente e constantemente controla a Igreja. As situações de conflito e oposição são descritas como "desobediência" e "corrupção", mas não nos termos e concepções da época. CAÑEQUE, Alejandro, The king's live image. The culture and politics of vicerregal power in colonial Mexico. Nova Iorque: Routledge, 2004, p. 76.
} 
arquiepiscopal sobre as ordens. ${ }^{107} \mathrm{~A}$ ausência de visitas pastorais às paróquias e doctrinas, ao longo do século XVII é destacada como evidência da autonomia e poder das ordens religiosas no arquipélago. Alexandre Coello de la Rosa aponta também para a ideia de frailocracia, indicando que a atuação das ordens "difilcutaron la imposición de políticas sistemáticas de confesionalización y de imposición de los principios tridentinos desde las instancias del poder diocesano." 108

No entanto, é preciso colocar em questão a ideia que o Concílio de Trento gerou "políticas sistemáticas". Como destaca Thomas Duve, analisando a produção de catecismos em Lima, o universalismo e centralismo tridentino não ignorava as realidades locais. Segundo Duve, a Igreja católica se regeu sobre uma lógica bipolar, exigindo o estabelecimento de um padrão de catecismo, mas considerando que tal padrão deveria ser adaptado às diversas realidades locais, como a língua. Portanto, conclui, Trento foi menos centralizador do que geralmente se propõe. ${ }^{109} \mathrm{Na}$ Nova Espanha a situação não foi distinta, os concílios mexicanos que sucederam ao Concílio de Trento não foram uma mera aplicação dos cânones tridentinos à realidade americana. Letícia Pérez Puente destaca muitas omissões a Trento nesse processo. Mais que isso, a historiadora mexicana aponta que o processo de afirmação da autoridade episcopal sob as ordens religiosas foi estabelecida "en la praxis política y no en la autoridad del tecer concilio". ${ }^{110}$ A atuação régia, por meio do Patronato, foi, afirma a historiadora, tão importante quanto a proposta de reforma eclesiástica.

Não se trata de negar que o clero regular de fato resistiu em manter a autonomia e autogoverno das próprias ordens, mas de colocar tais atitudes em perspectiva, considerando a especificidade das Filipinas. Tratava-se de um contexto com grande população clérigos regulares (em comparação ao total da população europeia), cuja presença nos rincões mais distantes do arquipélago eram, destaca Coello de la Rosa, de suma importância tanto para a

\footnotetext{
${ }^{107}$ COELLO DE LA ROSA, Alexandre. Los conflictos jurisdiccionales entre los arzobispos de Manila y los jesuitas por las doctrinas de indios (siglos XVI-XVIII). Boletín Americanista, n. 67, 2013.

${ }^{108}$ COELLO DE LA ROSA, Alexandre. Por qué no hubo campañas de extirpación de idolatrías en las Filipinas (siglo XVII)?. [em linha], ESpania, n. 33, 2019.

${ }^{109}$ DUVE, Thomas. Catequesis y derecho canónico entre el Viejo y el Nuevo Mundo. In: SCHMIDT-RIESE, Roland. Catequesis y derecho en la América colonial. Fronteras borrosas. Madri: Iberoamericana-Vervuert, 2010, p. 131-133.

${ }^{110}$ PÉREZ PUENTE, Leticia. Trento en México. El tecer concilio provincial mexicano. In: Derecho, historia y universidades. Estudios dedicados a Mariano Peset. V. II. Universitat de València, 2007, p. 420.
} 
Igreja quanto para a Coroa Espanhola. ${ }^{111}$ Abdicar da atuação de agostinianos, dominicanos, franciscanos e jesuítas não era uma opção em prol de garantir um suposto absolutismo episcopal.

A partir da segunda metade da década de 1590 vemos a insistência do clero filipino em vincular o cumprimento das leis e cédulas régias à consciência. Aqueles que não cumpriam, não eram apenas maus súditos, mas maus cristãos. Isso não quer dizer que defendiam a infalibilidade do monarca, mas entendiam que este agia baseado em preceitos religiosos, buscando o bem espiritual e temporal de seus súditos. No entanto, caso a orientação régia fosse oposta ao "bem maior", a manutenção do maior número de pessoas no caminho da salvação, os freis, padres e bispos não hesitavam em defender seu não cumprimento. Com isso, não diziam que o monarca era injusto - pois sempre destacaram suas boas intenções -, mas que estava malinformado por seus subalternos.

Por confessionalização, conforme promovido pela Igreja católica na Idade Moderna, entendo um sistema de disciplinarização, ou seja, "de ligar os corações à obediência". ${ }^{112}$ A participação dos crentes é uma das importantes evidências desse processo. Sem a preocupação da comunidade em ter sua consciência limpa, as prédicas, sermões e confissões seriam de pouco efeito. O respeito que governadores, encomenderos e outras pessoas mostravam diante das censuras lançadas pelos eclesiásticos das Filipinas são sinal disso. O governador que aceitou se casar, o capitão que abriu mão da pancada, os nativos que libertavam seus escravos entre outras ações, corroboram no mesmo sentido. Não se aceitava passivamente ficar em estado de pecado mortal, não desejavam ficar longos tempos sem receber o alívio da absolvição e não ousavam incorrer na pena de excomunhão. A busca pelo tribunal da Inquisição, seja pelas dezenas de réus que foram declarar seus próprios pecados, seja pelas indígenas que denunciaram seus confessores (geralmente orientadas por outros confessores), mostram o impacto que o modelo de controle das consciências surtiu no arquipélago.

Quando a questão se reduz a bispos (tridentinos) versus freis ("antitridentinos") temos não só um simplismo, mas um problema teórico-metodológico. A confessionalização é difusa.

\footnotetext{
${ }^{111}$ COELLO DE LA ROSA, 2019.

112 PROSPERI, 2013, p. 29.
} 
Os bispos foram figuras importantíssimas nesse processo, mas não os únicos. Diversos historiadores chamam a atenção para ver o Concílio de Trento como um marco, não um início ou fim a ser simplesmente executado. Muitas das normas e preceitos eclesiásticos não estavam claramente definidos após o encerramento da assembleia. O poder dos bispos era uma dessas questões. Foi nos conflitos e diálogos ocorridos a partir da década de 1560 que muito da Igreja católica reformada tomou corpo, num processo não linear. Conceber dicotomias desse tipo (incorrendo no maniqueísmo) promove a reprodução de várias falhas metodológicas.

A relação dos missionários e colonizadores com os nativos passou pelo mesmo processo. Não ocorreu a execução de diretrizes pré-definidas por Madri. Na lida cotidiana, nas estratégias de conversão, nos conflitos passados em campo que se estabeleceu uma "ortoprática". Isto é, entender que os sistemas de crenças e de administração destas crenças são construções históricas. ${ }^{113}$ A dinâmica entre diplomacia, amizade e guerra variava na mesma medida que os ventos do Pacífico.

Este, por sinal, foi um obstáculo que a Monarquía não encontrou em nenhum outro contexto. A morosidade na comunicação e a longuíssima distância do arquipélago para as demais partes do império demandaram formas de ação específicas, tanto na empresa colonial quanto na inspeção dos agentes coloniais. Agentes estes que estavam longe de serem homogêneos. Nem mesmo poderiam ser reduzidos à simplista divisão entre "braço secular" e "braço eclesiástico". As vozes eram múltiplas e se direcionavam em rumos ora distintos, ora opostos ou ora paralelos.

$\mathrm{Na}$ tarefa de orientar as mentes de suas “ovelhas", os "pastores” tinham várias roupagens: inquisidores, bispos, confessores, missionários, dentre outras. Estes, além de concorrerem entre si, com seus privilégios e jurisdições, adaptavam-se de maneira distinta aos diversos contextos políticos, geográficos, econômicos e sociais. As pautas da vida religiosa também variaram de acordo com o contexto. O bom tratamento aos nativos, tão caro aos freis e bispos atuantes nas Filipinas obviamente não estava no horizonte de uma boa vida cristã em Castela. O processo de confessionalização católica nas Filipinas não se deu da mesma forma na Itália, nas Canárias ou

${ }^{113}$ GASBARRO, Nicola. "Missões: a civilização em ação”. In: MONTEIRO, Paula (org.). Deus na aldeia: missionários, índios e mediação cultural. São Paulo: Globo, 2006. 
na Nova Espanha. A especificidade "secular" do Sínodo de Manila ao estabelecer padrões que os agentes seculares (rei, governador, alcaides, encomenderos etc.) deveriam ter, a fim de orientar os confessores, é uma forte evidência disso. Diferente dos concílios e sínodos americanos, a estrutura eclesiástica esteve longe de ser a principal questão da assembleia episcopal.

A especificidade da situação filipina deve ser vista no estudo das práticas cotidianas, relatadas nos documentos paroquiais, nos processos inquisitoriais, nas disposições do sínodo de Manila, nas correspondências dos religiosos e nas missivas de autoridades seculares. No entanto, esse olhar detalhado não pode fazer com que se perca uma concepção macro dos processos de confessionalização. O que se passa nas Filipinas é parte de uma configuração mais ampla, e chama a atenção justamente por ser parte dessa configuração.

Se as denúncias de corrupção moral do clero foram muitas é porque a situação era incômoda, e partiam de dentro das próprias ordens religiosas. A ação de institutos, que exerciam princípios tridentinos, como as visitas e o tribunal do Santo Ofício, junto da ação de bispos sufragâneos, cabildo eclesiástico e prelados das ordens surtiram efeito. Portanto, a ideia de reforma do clero, tão cara ao Concílio de Trento ${ }^{114}$, não ficou alheia à história eclesiástica do arquipélago filipino. As instituições eclesiásticas insistiam no seu intento de buscar membros de vida correta. Exemplo é um instituto elaborado pelo bispo de Santíssimo Nome de Jesus, frei Pedro Arce, e pelo cabildo eclesiástico, em agosto de 1617. Pautados no Concílio Mexicano, os eclesiásticos pediram que os religiosos expulsos das ordens não recebessem dignidades, curatos, prebendas ou benefícios. Se tais pessoas não serviam para as religiões também não eram úteis para o clero secular, como "la esperiencia a mostrado". Pois era exigido "que los ministros dotrineros sean de buena vida y costumbres por conbenir asi al bien de la christiandad de los naturales". 115

\footnotetext{
${ }^{114}$ PROSPERI, 2001, p. 73-87.

115 AGI, Petición del cabildo eclesiástico de Manila sobre no admitir religiosos expulsos como clérigos, Filipinas, 77, 42, img. 1.
} 


\section{REFERÊNCIAS}

\section{Fontes}

ARCHIVO GENERAL DE INDIAS (AGI). Carta de Tello sobre religiosos y sus necesidades, Filipinas, 18 b, 8, 106.

. Carta de agustinos de Manila sobre varios asuntos, Filipinas, 79, 59.

. Carta de agustinos en favor de Acuña y pidiendo religiosos, Filipinas, 84, 30.

. Carta de Alvarado sobre muertes de dela Vega y Sepulveda, Filipinas, 20, 11, 71.

. Carta de Domingo de Salazar resumiendo seis cartas, Filipinas, 74, 35.

. Carta de Domingo de Salazar sobre conflicto con Diego de Mujica, Filipinas, 84, 24.

. Carta de dominicos a Miguel de Benavides o al procurador en la corte, Filipinas, 84, 66.

. Carta de dominicos en favor de los agustinos, Filipinas, 84, 121.

. Carta de franciscanos sobre mal estado de las Filipinas, Filipinas, 85, 24;.

_. Carta de Ignacion de Santíbañez quejándose de Tello, Filipinas, 74, 42. 20, 6, 47.

. Carta de la Audiencia de Manila sobre necesidad de monasterio de monjas, Filipinas,

_. Carta de la Audiencia de Manila sobre religiosos e clérigos, Filipinas, 18 a, 5, 33.

_. Carta de la Audiencia de Manila sobre situación y necesidades, Filipinas, 18 a, 3, 13.

_. Carta de las órdenes religiosas sobre estado de las Filipinas, Filipinas, 79, 27.

_. Carta de los agustinos contra fray Lorenzo de León, Filipinas, 79, 52.

. Carta de los agustinos de Manila sobre visita de fray Pedro de Sosa, Filipinas, 84, 103.

. Carta de los agustinos pidiendo que se visite su orden, Filipinas, 84, 143.

. Carta de Tello sobre arzobispo y religiosos, Filipinas, 6, 9, 169.

. Carta de Tello sobre presentaciones de la Catedral, Filipinas, 19, 3, 50.

. Carta de Vera pidiendo plaza de oidor de México, Filipinas, 18 a, 3, 17.

. Carta de Vera sobre necesidades, indios, minas etc, Filipinas, 18 a, 3, 15. 
. Carta del agustino Alonso de Vico sobre reforma de los agustinos, Filipinas, 84, 78. . Carta del agustino Juan de Tapia sobre reforma de los agustinos, Filipinas, 84, 135. . Carta del cabildo eclesiástico de Manila sobre varios asuntos, Filipinas, 84, 128.

- Carta del cabildo eclesiástico denunciando persecución de fray Diego de Soria, Filipinas, 84, 75.

. Carta del cabildo secular de Manila sobre asuntos generales, Filipinas, 34, 62;

. Carta del cabildo secular de Manila sobre estado de las islas, Filipinas, 36, 39.

- Carta del dominico Bernardo de Santa Catalina denunciando el governador de las Filipinas, Filipinas, 84, 83

. Carta del dominico Bernardo de Santa Catalina sobre varios asuntos, Filipinas, 79, 73.

. Carta del dominico Juan de San Pedro Mártir sobre los chinos, Filipinas, 79, 32.

. Carta del dominico Miguel de San Jacinto sobre agravios a indios y otros asuntos, Filipinas, 85, 25.

. Carta del fiscal Ayala sobre situación general, Filipinas, 18 a, 7, 49.

- Carta del franciscano Juan de Garrovillas en favor de los agustinos de Filipinas, Filipinas, 84, 123.

. Carta del jesuíta Gregorio López sobre estado de Filipinas, Filipinas, 79, 64.

150

Carta del maestreescuela Luis de Salinas sobre denuncias que ha hecho, Filipinas, 84,

. Carta del obispo de Cebú, Pedro de Agurto, sobre varios asuntos, Filipinas, 76, 3.

. Carta del obispo de Nueva Segovia, Miguel de Benavides, denunciando la situación de Filipinas, Filipinas, 76, 42.

. Carta del obispo de Nueva Segovia, Miguel de Benavides, informando del estado de las islas, Filipinas, 76, 3.

. Carta del obispo de Nueva Segovia, Miguel de Benavides, sobre conversión y vasallaje de los naturales, Filipinas, 76, 44.

. Carta del obispo de Nueva Segovia, Miguel de Benavides, sobre quejas de los chinos, Filipinas, 76, 41. 
. Carta do cabildo eclesiástico sobre o comercio de Filipinas com Nova Espanha, Filipinas, 77, 6;

_. Carta do cabildo eclesiástico, Filipinas, 77, 8.

. Carta do cabildo eclesiástico, Filipinas, 77, 9.

. Cartas de Domingo de Salazar al rey, Patronato Real, 25, 8.

. Cartas del dominicano Diego de Soria sobre su persecución, Filipinas, 84, 76.

. Causa contra religiosos sobre doctrinas de índios, Filipinas, 84, 55.

. Consulta del consejo de Indias, Indiferente General, 739, 99.

_. Copia de carta de G. P. Mariñas quejándose del obispo Filipinas, 18 b, 1, 3.

1. . Copia de carta sobre estado de las Filipinas y posibilidades del comercio, Filipinas, 79,

. Descubrimientos, poblaciones de españoles: Filipinas, Patronato Real, 23, 9;.

_. Expediente sobre comercio de Filipinas con China, Filipinas, 18a, 8, 53.

_. Información sobre negativa del obispo a dar doctrina, Filipinas, 6, 7, 77.

_. Parecer de religiosos sobre cédula de la esclavitud, Filipinas, 84, 21.

. Petición del cabildo eclesiástico de Manila sobre no admitir religiosos expulsos como clérigos, Filipinas, 77, 42.

.Petición del agustino Diego de Guevara sobre viaje a Filipinas y despachos de religiosos, Filipinas, 79, 84.

. Petición del agustino Miguel García de licencia para 50 religiosos, Filipinas, 85, 26.

. Petición del agustino Tomás Márquez de varias mercedes, Filipinas, 79, 117.

. Recomendación de Silva para que se de obispado a Salas, Filipinas, 7, 4, 50.

. Registro de oficio de la Audiencia de Filipinas, Filipinas, 329, L. 1.

. Registro de oficio de la Audiencia de Filipinas, Filipinas, 329, L. 2.

. Registro de ofício y partes de disposiciones reales, Filipinas, 339, L. 1.

. Registro de ofício y partes de disposiciones reales, Filipinas, 339, L. 2. 
. Relación de agustinos que pasan con fray Pedro de Solier, Filipinas, 79, 56.

ARCHIVO GENERAL DE LA NACIÓN [México] (AGN). Cartas del fray Bernardo de Santa Catalina, comisario del Santo Oficio en Manila, Indiferente Virreinal, c. 3436, exp. 38.

. Cartas del licenciado Davalos oidor del Santo Oficio para los señores inquisidores de México, Indiferente Virreinal, c. 5025, exp. 25.

Correspondencia del comisario del Santo Oficio de Manila, fray Bernardo de Santa Catalina, Indiferente Virreinal, c. 5172, exp. 85.

Declaración contra Hernando Basques, religioso de la compañía de Jesús por haber tenido acceso carnal con una india, Indiferente Virreinal, c. 5596, exp. 11. exp. 20.

Denuncia ante la Inquisición contra fray Diego Negrete, Indiferente Virreinal, c. 4154,

Denuncia ante la Inquisición por María Sanayin contra el pároco del pueblo de Bulacan por querer cometer actos ilícitos con ella, Indiferente Virreinal, c. 4154, exp. 5.

- Denuncia contra fray Diego Pardo por hacer solicitaciones después de haber santiguado, por una india llamada María Combocha, Indiferente Virreinal, c. 3436, exp. 42.

Denuncia de Ines Singo antes la Inquisición contra frailes franciscanos por cometer actos ilícitos con ella, Indiferente Virreinal, c. 4154, exp. 21.

- Denuncia hecha contra fray Lucas de Salas de la orden de San Agustín, por Agustina de Saen por haberle hecho solicitación, Indiferente Virreinal, c. 3436, exp. 28.

. Inquisición, 142.

. Inquisición, 86, img. 111.

. Inquisición, v. 139.

. Inquisición, v. 223.

Inquisión, v. 1494.

. Inquisión, v. 263.

. Memoria de testificaciones que se envian a la Santa Inquisición de México por los años de 1608 y 1609, Indiferente Virreinal, c. 2660, exp. 31.

Oficio de recibo de la noticia de 35 testificaciones para solicitantes en el Santo Oficio, Indiferente Virreinal, c. 2660, exp. 11. 
Petición de fray Francisco de Herrera de darle solución al problema de que frailes piden a indias presentarse a confesión para tener actos ilícitos con ellas, Indiferente Virreinal, c. 4154, exp. 35.

Razón dada a la Inquisición sobre recibo de despachos sobre el capitán Pedro de Busto y Lucas de Mañozca; sobre un romance que tiene fray Cristóbal de Fonseca, agustino, Indiferente Virreinal, c. 4154, exp. 33.

. Relación de denuncias hechas en la comisaría del arzobispado de Manila desde el año 1606 y 1607, Indiferente Virreinal,c. 3436, exp. 30;

. Relación de la comisaría del arzobispado de Manila desde la partida de los navios de 1607, Indiferente Virreinal, c. 2660, exp. 12.

. Relación de las causas del año de 1605, por fray Bernardo de Santa Catalina, Indiferente Virreinal c. 2660, exp. 15.

. Relación de las denuncias hechas antes la Inquisición, Indiferente Virreinal, c. 4154, exp. 26.

. Relación de los navios que zarparon a la Nueva España desde Manila en el año de 1604, Indiferente Virreinal, c. 2660, exp. 16.

ARCHIVO HISTÓRICO NACIONAL [Espanha] (AHN). Estado religioso en Filipinas, Diversos-colecciones, 26, 10.

Memorial de las cosas que en estas yslas Philipinas de Poniente pasan y del estado de ellas y de lo que hay que remediar, hecho por fray Domingo de Salazar, Obispo de las dichas yslas, Para que lo vea Su Magestad y los Señores de su Real Consejo de Yndias. 1583. China en España (CHE). "Elaboración de un corpus digitalizado de documentos españoles sobre China de 1555 a 1900". Disponível em: < http://www.upf.edu/asia/projectes/che/principal.htm >. Acesso: set. 2021.

MORGA, Antonio de. Sucesos de las Islas Filipinas. Enriquecida con los escritos inéditos del mismo autor. Madri: Librería General de Victoriano Suárez, 1909.

VITÓRIA, Francisco de. "Relección de la potestad civil”, In: Relecciones teologicas del p. fray Francisco de Vitoria. Madri: Librería Religiosa Hernández, 1917(a). T. II

"Relección de la postestad de la Iglesia". In: Relecciones teologicas del p. fray Francisco de Vitoria. Madri: Librería Religiosa Hernández, 1917(b). T. II

Obras Gerais 
CAÑEQUE, Alejandro. The king's live image. The culture and politics of vicerregal power in colonial Mexico. Nova Iorque: Routledge, 2004.

CERVERA, Antonio. Los dominicos y los chinos de Manila: Domingo de Salazar y Juan Cobo en Filipinas, 1581-1592. In: FUENTES, Paulina et. al. [coords.]. Pensamiento en México: tradiciones multiculturales. São Luis Potosi: Ed. UASLP, 2020.

COELLO DE LA ROSA, Alexandre. Los conflictos jurisdiccionales entre los arzobispos de Manila y los jesuitas por las doctrinas de indios (siglos XVI-XVIII). Boletín Americanista, $\mathrm{n}$. 67, 2013.

. Por qué no hubo campañas de extirpación de idolatrías en las Filipinas (siglo XVII)?. [em linha], E-Spania, n. 33, 2019.

CONSTANTINO, Renato. A History of the Philippines: from the Spanish Colonization to the Second World War. Nova Yorque: Monthly Review Press, 1975;

CREWE, Ryan Dominic. Pacific Purgatory: Spanish dominicans, chinese sangleys, and the entanglement of mission and commerce in Manila, 1580-1620. Journal of Early Modern History, v. 19, n. 4, 2015.

CUNNINGHAM, Charles Henry. The ecclesiastical influence in the Philippines. The American journal of theology, v. XXII, n. 2, 1918.

DE BOER, Wietse. The conquest of the soul. Confession, discipline and public order in counterreformation Milan. Boston: Brill, 2001.

DE LOS ARCOS, María Fernanda, Estado y clero en las Filipinas del siglo XVIII. Iztapalapa: Universidad Autónoma Metropolitana, 1988.

DEL PILAR, Marcelo. La frailocracia filipina. Barcelona: Imprenta Iberica de Francisco Fossas, 1889.

DUVE, Thomas. Catequesis y derecho canónico entre el Viejo y el Nuevo Mundo. In: SCHMIDT-RIESE, Roland. Catequesis y derecho en la América colonial. Fronteras borrosas. Madri: Iberoamericana-Vervuert, 2010.

GARCÍA-ABÁSOLO, Antonio. Relaciones entre los grandes virreyes de México y los agustinos ante la presencia española en Filipinas (siglo XVI). In: Actas del congresso internacional: Agustinos en América y Filipinas, Valladolid: Banco Atlántico, 1990, v. 2;

La primera exploración del Pacífico y el asentamiento español en Filipinas. In: ELIZALDE, M. (Org.). Las relaciones entre España y Filipinas. Siglos XVI-XX. Madri: CSIC, 2002. 
GARCÍA-GARRIDO, Manuela. Desobediencia y conflictos en el clero de las islas Filipinas (1595-1615). Nuevo Mundo, Mundos Nuevos [em linha], 2015.

Peticiones contra el 'breve de la alternativa' o el rechazo de la hibridacion clerical en Filipinas [em linha]. E-Spania, n. 30, 2018.

GARRIGA, Carlos. Orden jurídico y poder político en el Antiguo Régimen. Istor, n. 16, 2004.

Sobre el gobierno de la justicia en Indias (siglos XVI-XVII). Revista de Historia del Derecho, n. 34, 2006.

GASBARRO, Nicola. Missões: a civilização em ação. In: MONTEIRO, Paula (Org.). Deus na aldeia: missionários, índios e mediação cultural. São Paulo: Globo, 2006.

HALICZER, Stephen. Sexualidad en el confesionario. Un sacramento profanado. Madri: Siglo XXI, 1998.

HESPANHA, António M. Para uma teoria da história institucional do Antigo Regime. In: HESPANHA, A. (Org,). Poder e instituições na Europa do Antigo Regime: coletânea de textos. Lisboa: Gulbenkian, 1984.

HIDALGO NÚCHERA, Patricio, Encomienda, tributo y trabajo en Filipinas (1570-1608). Madri: Universidad Autónoma de Madrid, 1995.

LUNDBERG, Magnus. Church life between the Metropolitan and the local. Parishes, parishioners and parish priests in seventeenth-century Mexico. Madri: Iberoamericana, 2011.

MACKAY, Ruth. The limits of Royal Authority: resistance and obedience in seventeenthcentury Castile. Nova Iorque: Cambridge University Press, 1999.

MELVIN, Karen. Building colonial cities of God. Mendicant orders and urban culture in New Spain. Stanford: Stanford University Press, 2012.

NADEAU, Kathleen. The history of the Philippines. Londres: Greenwood, 2008.

OLLÉ RODRÍGUEZ, Manel. Estrategias filipinas respecto a China: Alonso Sánchez y Domingo Salazar en la empresa e China (1581-1593). Tese (Doutorado), Universitat Pompeu Fabra, Barcelona, 1998.

ORTIZ ARMENGOL, Pedro. Letras en Filipinas. Madri: Dirección General de Relaciones Culturales y Científicas, 1999.

PALANCO AGUADO, Fernando. Los primeros años de Inquisición en Filipinas. Jueces eclesiásticos, el obispo Domingo de Salazar y los comisarios agustino fray Francisco Manrique y fray Diego Muñoz (1577-1594). Archivo Augustiniano, v. 102, n. 220, 2018. 
PÉREZ PUENTE, Leticia. Trento en México. El tecer concilio provincial mexicano. Derecho, historia y universidades. Estudios dedicados a Mariano Peset. V. II. Universitat de València, 2007.

. El obispo. Político de institución divina. In: MARTÍNEZ, Maria (Org.). La Iglesia en Nueva España. Problemas y perspectivas de investigación. México: UNAM, 2010.

PORRAS CAMUÑEZ, José Luis. La posición de la Iglesia y su lucha por los derechos del indio filipino en el siglo XVI. Tese de doutorado. Sevilha: Universidade de Sevilha, 1985.

PROATTI, Elaine. Consciência e lei: os embates subjetivos e teológicos nos pareceres do Padre Fray Miguel Agia. Dissertação de mestrado. São Paulo: Universidade Federal de São Paulo, 2015.

PRODI, Paolo. Uma história da justiça: do pluralismo dos foros ao dualismo moderno entre consciência e direito. São Paulo: Martins Fontes, 2005.

PROSPERI, Adriano. Il Concilio di Trento: una introduzione storica. Turim: Giulio Einaudi, 2001. $\overline{2013}$.

Tribunais da Consciência. Inquisidores, confessores, missionários. São Paulo: Edusp,

RIOS VICENTE, Enrique. Marcelo H. del Pilar, el mejor comunicador filipino de finales del siglo XIX. Revista de la SEECI, n. 5, 2000.

RODRIGUES, Rui Luis. Os processos de confessionalização e sua importância para a compreensão da história do Ocidente na primeira modernidade (1530-1650). Tempo, v. 23, n. $1,2017$.

ROCHA, Carlos. Para a conversão das almas: conquista espiritual, governo civil e defesa dos nativos nas Filipinas. A época missionária, 1565-1581. Diálogos, v. 20, n. 2, 2016.

RUBIAL, Antonio, "Las ordenes mendicantes evangelizadoras en Nueva España y sus câmbios estructurales durante los siglos vierreinales". In: MARTÍNEZ, Maria (Org.). La Iglesia en Nueva España. Problemas y perspectivas de investigación. México: UNAM, 2010.

RUIZ, Rafael. Os espaços da ambigüidade: os poderes locais e a justiça na América Espanhola do século XVII. Revista de História, n. 163, 2010.

TORIBIO MEDINA, José. El tribunal del Santo Oficio de la Inquisición en las islas Filipinas. Santiago: Imprenta Elzeviriana: 1899.

Recebido em: 20/11/2020 - Aprovado em: 11/10/2021 